\title{
Thickening and exhumation of the Variscan roots in the Iberian Central System: Tectonothermal processes and ${ }^{40} \mathrm{Ar} /{ }^{39} \mathrm{Ar}$ ages
}

\author{
Francisco J. Rubio Pascual ${ }^{\mathrm{a}, *}$, Ricardo Arenas ${ }^{\mathrm{b}}$, José Ramón Martínez Catalán ${ }^{\mathrm{c}}$, \\ L. Roberto Rodríguez Fernández ${ }^{\mathrm{a}}$, Jan R. Wijbrans ${ }^{\text {a }}$ \\ a Instituto Geológico y Minero de España, Ríos Rosas 23, 28003 Madrid, Spain \\ b Departamento de Petrología y Geoquímic e Instituto de Geociencias (UCM-CSIC), Universidad Complutense, 28040 Madrid, Spain \\ ${ }^{c}$ Departamento de Geología, Universidad de Salamanca, 37008 Salamanca, Spain \\ d Department of Isotope Geochemistiy, Vrije Universiteit, Amsterdam $1081 \mathrm{HV}$, The Netheriands
}

Keywords:

Variscan metamorphism

Barrovian to low-P evolution

${ }^{40} \mathrm{Ar} /{ }^{39} \mathrm{Ar}$ geochronology

Iberian Massif

\begin{abstract}
A B S T R A C T
$\overline{40} \mathrm{Ar} /{ }^{39} \mathrm{Ar}$ dating of white mica in metapelites, thermobarometric calculations and new structural and geological mapping have been carried out in the Somosierra region (Iberian Central System, ICS) to investigate the Variscan thickening-exhumation processes and the evolution of the paleo-thermal structure in a key region of the Central Iberian Zone. The rocks underwent an in termediate P/T event (M1) during a D1 stage of crustal thickening initiated between 354 and 347 Ma. This event was probably related to a first S to SE-directed emplacement of the NW Iberian al loch thon, and during the initial development of a mid-crustal subhorizontal shear zone accommodating the ductile flow of thermally weakened crust parallel to the main orogenic trend. Syn-convergent extension of the upper levels occurred by 335-327 Ma, when tectonic unroofing led to D2 domal uplift of the orogenic roots and to recrystallization of rocks under intermediate to low P/T conditions (M2). Individualized gneiss domes developed along the orogenic trend, whereas some post-M2 thrusts dated at $c$. $319 \mathrm{Ma}$ reflect lateral flow related to limited gravitational spreading of the domes. Younger upright to SW verging folding of the ICS dome during D3 progressive renewal of contractive deformation took place after 316 Ma. Final D4 gravitational collapse occurred under low P/T conditions (M3) at c. $300 \mathrm{Ma}$, accompanied by the intrusion of large volumes of anatectic granitoids.
\end{abstract}

\section{Introduction}

Escape tectonics is well documented in Alpine chains, such as the Himalayas (Tapponnier and Molnar, 1976), the western Alps (Tapponnier, 1977), the eastern Alps (Selverstone, 1988) or central Anatolia (Dewey et al, 1986), and also has been recognized in older belts such as the SWEuropean Variscan orogen (Dias and Ribeiro, 1995; Martínez Catalán, 1990). The Iberian Massif ransect of the Variscan chain provides an excellent opportunity to study orogenic processes at different structural levels. Its tectonometamorphic evolution has been interpreted as a record of oblique collision (Badham and Halls, 1975) accompanied by complex gravitational adjustments (Aerden, 2004; Martínez Catalán et al., 2007; Simancas et al., 2001). This paper focuses on the Iberian Central system where the exhumation of deeply buried crustal levels (Pérez-Estaún et al., 1991) has been explained through orthogonal thickening and parallel gravitationally-induced extension
(Escuder Viruete et al., 1994; Díez Balda et al., 1995; Escuder Viruete et al, 1994, 1998). New structural and geological mapping, thermobarometric calculations and ${ }^{40} \mathrm{Ar} /{ }^{39} \mathrm{Ar}$ dating constraints, suggest a thickening context dominated by plate boundary-constricted flow (tectonic escape; Molnar and Tapponnier, 1975) and gravity-driven flow (gravitational collapse; Ramberg, 1980; gravitational spreading; England, 1982) parallel to what has been traditionally considered the orogenic trend.

\section{Geological setting and tectonic units}

An almost complete section of the upper and middle crustal rocks crops out in the Somosierra region of the Iberian Central System (ICS), one of the most internal domains of the Variscan Orogen in the Central Iberian Zone (CIZ) of the Iberian Massif (Fig. 1). The region is characterized by a Barrovian metamorphism, overprinted by two later stages of lower $P / T$ conditions and syntectonic partial melting, that produced widespread migmatites (Arenas, 1991; Arenas et al., 1991; Bischoff et al., 1973; Escuder Viruete et al., 1994, 1998; Martínez et al., 1988) and late to post-tectonic granitoid intrusions. By contrast, the West Asturian-Leonese Zone (WALZ) situated to the north and east of the study area as well as the southern part of the CIZ, represent more external domains of the Variscan orogen that exhibit only low-grade regional 


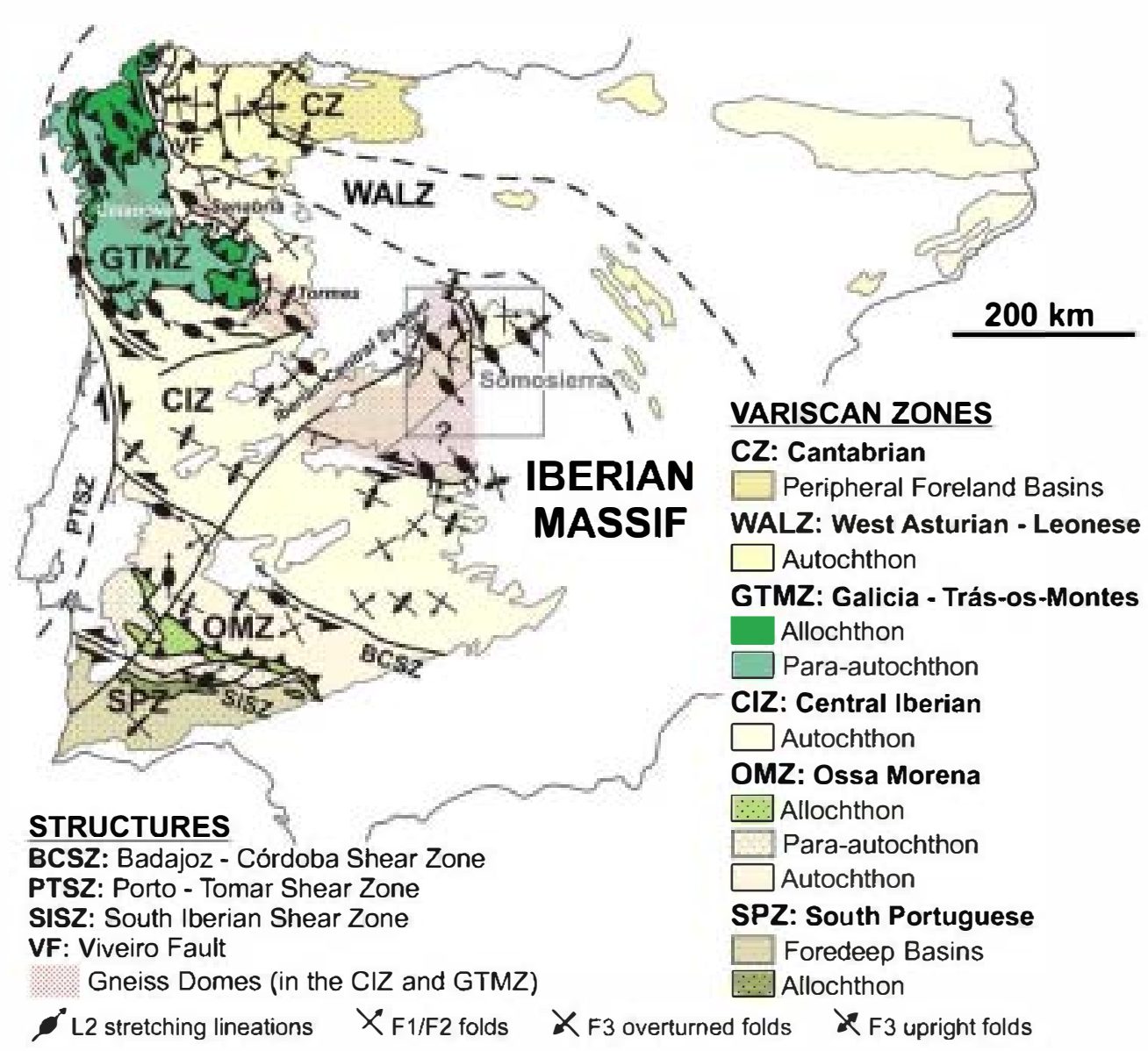

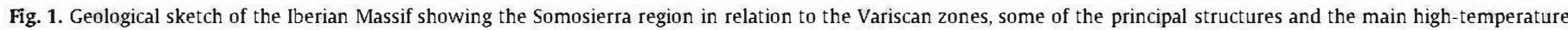

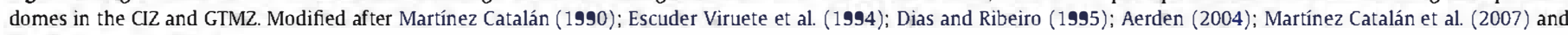
Martínez Catalán (2011).

metamorphism even at relatively deep structural levels. The absence of large recumbent folds or nappes associated with crustal thickening stages in the Central Iberian Zone, has raised questions about the mechanism that was responsible for deep burial of rocks, Barrovian metamorphism and subsequent metamorphic and igneous processes (Escuder Viruete et al., 1994; Macaya et al, 1991; Martínez et al., 1988).

Three tectonic units with different deformative, metamorphic and lithostratigraphic characteristics can be distinguished in the ICS (Fig. 2). The contacts between them are syn to late-orogenic extensional structures, except for some post-metamorphic thrusts.

The Lower Unit is partially equivalent to the Lower Unit of Escuder Viruete et al. (1994) in the Tormes Gneiss Dome. It is formed here by over $6500 \mathrm{~m}$ of Neoproterozoic to Early Cambrian metasediments, migmatitic semipelitic and quartz-feldspathic gneisses and mylonitic pelitic gneisses (Bischoff et al., 1973), and large volumes of Early Ordovician orthogneisses (Valverde-Vaquero and Dunning, 2000; Vialette et al., 1987). Some quartzites, coarse-grained siliciclastic rocks, calc-silicate rocks, marbles, scarce amphibolites and rare retrogressed eclogites are also present. Most of the Lower Unit crop out in a huge crescent-shaped domal structure (Fig. 1) oriented roughly NE-SW, but they also appear in the cores of NW-SE D3 antiforms (Fig. 2). The rocks have experienced a D1 crustal thickening episode (Macaya et al., 1991; Pérez-Estaún et al., 1991) under intermediate P T gradients (M1; Arenas et al., 1991), but those in the domal structure were intensely recrystallized under higher temperatures and lower pressure conditions (M2 of Arenas et al., 1991; M2 and M3 herein) during D2 synconvergent orogen-parallel extension (Escuder Viruete et al., 1998), D3 upright folding and D4 extensional collapse (Doblas, 1991).
The Middle Unit (Fig. 2) is formed by $1500 \mathrm{~m}$ of Neoproterozoic to Early Cambrian metasedimentary rocks including mylonitic schists and gneisses, black graphitic quartzites, coarse-grained siliciclastic rocks and calc-silicate rocks, plus Early Ordovician leuco-gneisses (Valverde-Vaquero and Dunning, 2000; Vialette et al., 1987). It is equivalent to the upper part of the Lower Unit in Escuder Viruete et al. (1994). Despite an intense D2 deformation, the rocks preserve M1 Barrovian mineral associations (kyanite, staurolite, almandine gamet) which have been overprinted by the M2 and M3 lower P/T events in the higher grade domains. The intense deformation in this unit represents the main part of a D2 ductile detachment zone of regional scale (Macaya et al., 1991), generally referred to as the Berzosa Shear Zone (BSZ; Capote et al., 1977; Arenas et al., 1982; Escuder Viruete et al., 1998). The BSZ produces crustal thinning and telescoping between the high grade Lower Unit and the low grade Upper Unit, which are also partially affected by D2 deformation (Fig. 2).

The Upper Unit (Fig. 2) is equivalent to the Upper Unit of Escuder Viruete et al. (1994) in the Tormes Gneiss Dome. It consists of nearly $7500 \mathrm{~m}$ of Paleozoic metapelites and metapsamites, ranging from Early Ordovician (locally Early Cambrian) to Early Devonian in age (Bischoff et al., 1973). Early Ordovician felsic metavolcanic rocks (Gebauer et al., 1993; Montero et al., 2007; Valverde-Vaquero and Dunning, 2000) of the Ollo de Sapo Formation occur at or near its base. An S1 foliation, axial planar to F1, and E-vergent folds, are well preserved above the D2 shear zone (Escuder Viruete et al., 1998; Macaya et al., 1991). Barrovian metamorphic zones (M1) were folded by D3 (Martínez Catalán et al., 2007), but do not exhibit major low pressure (M3) overprinting, except for areas adjacent to the high grade dome (Fig. 3). 


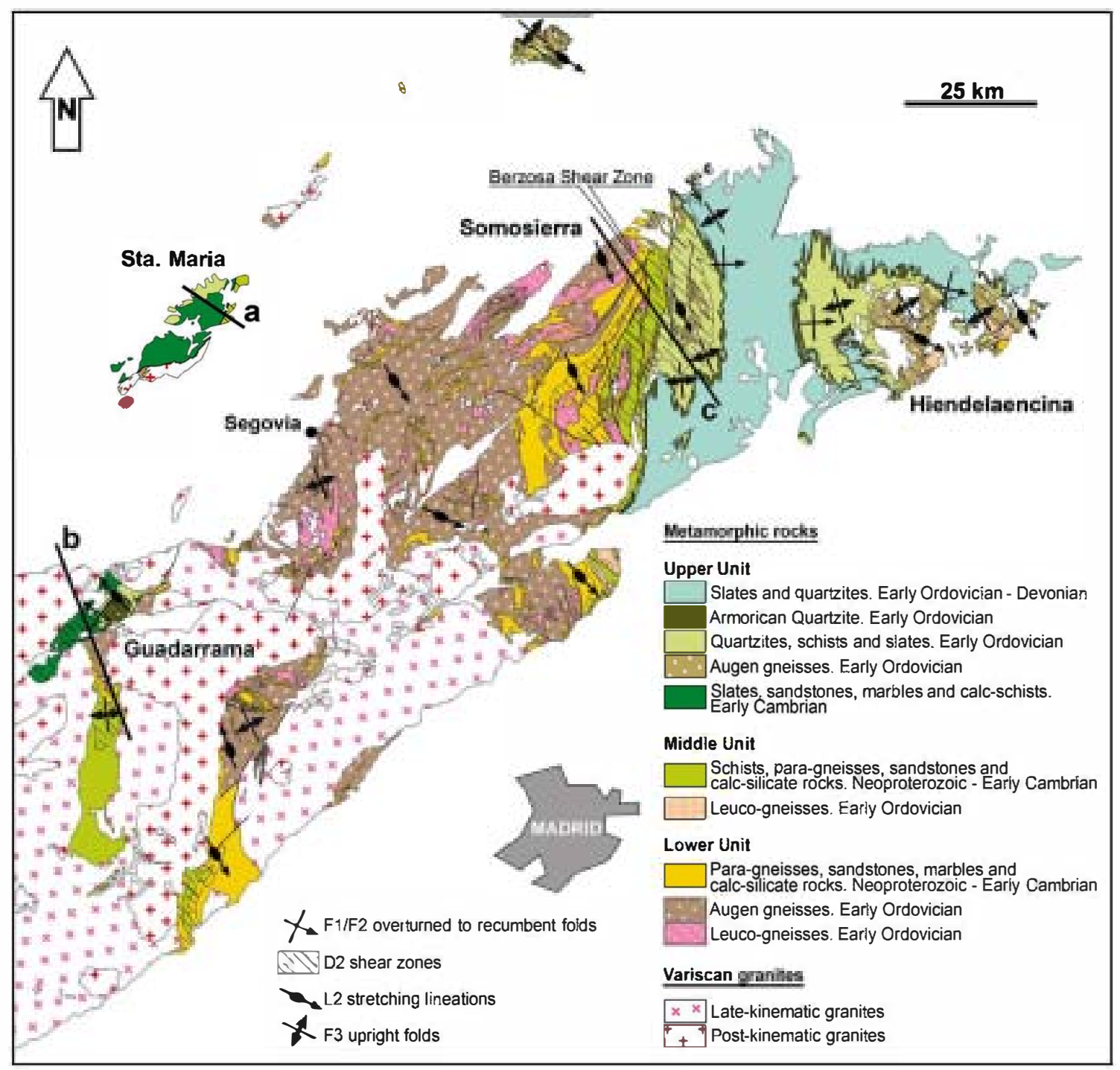

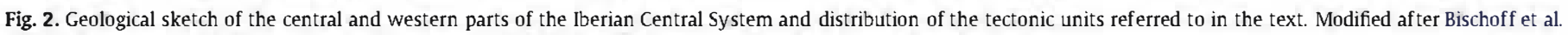
(1973); Macaya et al. (1991) and Escuder Viruete et al. (1998). Simplified cross-sections (a, b, c) are shown in Fig. 4.

\section{Tectonic evolution}

Four main Variscan deformation events characterize the tectonothermal evolution of the Somosierra region (Macaya et al., 1991). A first crustal thickening event (D1; Pérez-Estaún et al., 1991) produced E-vergent, kilometer-scale, asymmetric isoclinal folds, scarce and only preserved at upper structural levels, while the rocks of the Lower Unit were buried at depths around $42 \mathrm{~km}$ ( $14 \mathrm{kbar}$; Barbero and Villaseca, 2000). S1 is a slaty cleavage associated with F1 folds, that constitutes the most pervasive fabric in the uppermost part of the Upper Unit (Fig. 4). It is also locally preserved as a relict internal schistosity in syn-D2 porphyroblasts of biotite, chloritoid, garnet and staurolite of the lower structural levels. The lower limit of well-preserved S1 in the area is a narrow band of S2 crenulation cleavage (Escuder Viruete et al., 1998), roughly dipping to the SE from the biotite to the gamet M1 metamorphic zones.

D2 is a deformation event characterized by subhorizontal topto-the-SE directed shearing (Diez Balda et al., 1995), i.e. parallel to the orogenic trend. The BSZ is characterized by a broad zone of S2 mylonitic foliation (Macaya et al, 1991), including from S to L-S tectonites, which is affecting the Middle Unit and adjacent parts of the Upper and Lower units. NW-SE-oriented $\mathrm{F} 3$ folds and crenulation cleavage overprinted $\mathrm{S} 2$, but maintained (or reoriented) the $\mathrm{L} 2$ stretching lineation, which plunges gently to steeply $\left(25-75^{\circ}\right)$ to the SE. The general linematics of D2 (Fig. 4) as deduced from asymmetric strain shadows of porphyroblasts and sigmoidal quartz veins is top-to-the-SE (Escuder Viruete et al., 1998). However, some cross-cutting narrow shear bands and most of the NW part of the metamorphic dome have top-to-the-NW shear-sense as indicated by $\mathrm{S}-\mathrm{C}$ fabrics and NW-vergent $\mathrm{F} 2$ recumbent folds with their axes oriented perpendicular to stretched pebbles and ichnofossils defining L2. The lowermost part of the Lower Unit presents an early syn-D2 migmatitic foliation which is finally affected by the BSZ and by other low angle SE- and NW-directed mylonitic bands (Doblas et al., 1994; Macaya et al., 1991). A few late- to post-D2 thrusts locally emplaced high-grade rocks of the Lower Unit, presently preserved as klippen, towards the ESE upon the Middle Unit. These structures cut and duplicate the M2 zoning but were affected by D3 folding. Other comparable thrusts are also found in the Upper Unit.

The main structures in the region (Figs. 1 and 2) are kilometer-scale, upright to SW-vergent, and F3 folds with NW-SE to N-S strike (Macaya et al., 1991; Pérez-Estaún et al., 1991). An associated axial-plane crenulaton cleavage (S3) is particularly well developed in hinge zones. D3 structures fold M1 and M2 isograds but do not fold the M3 metamorphic zoning.

D4 structures include low dipping crenulation cleavage and associated, up to several tens of $\mathrm{km}$ long shear bands with normal dip- or 


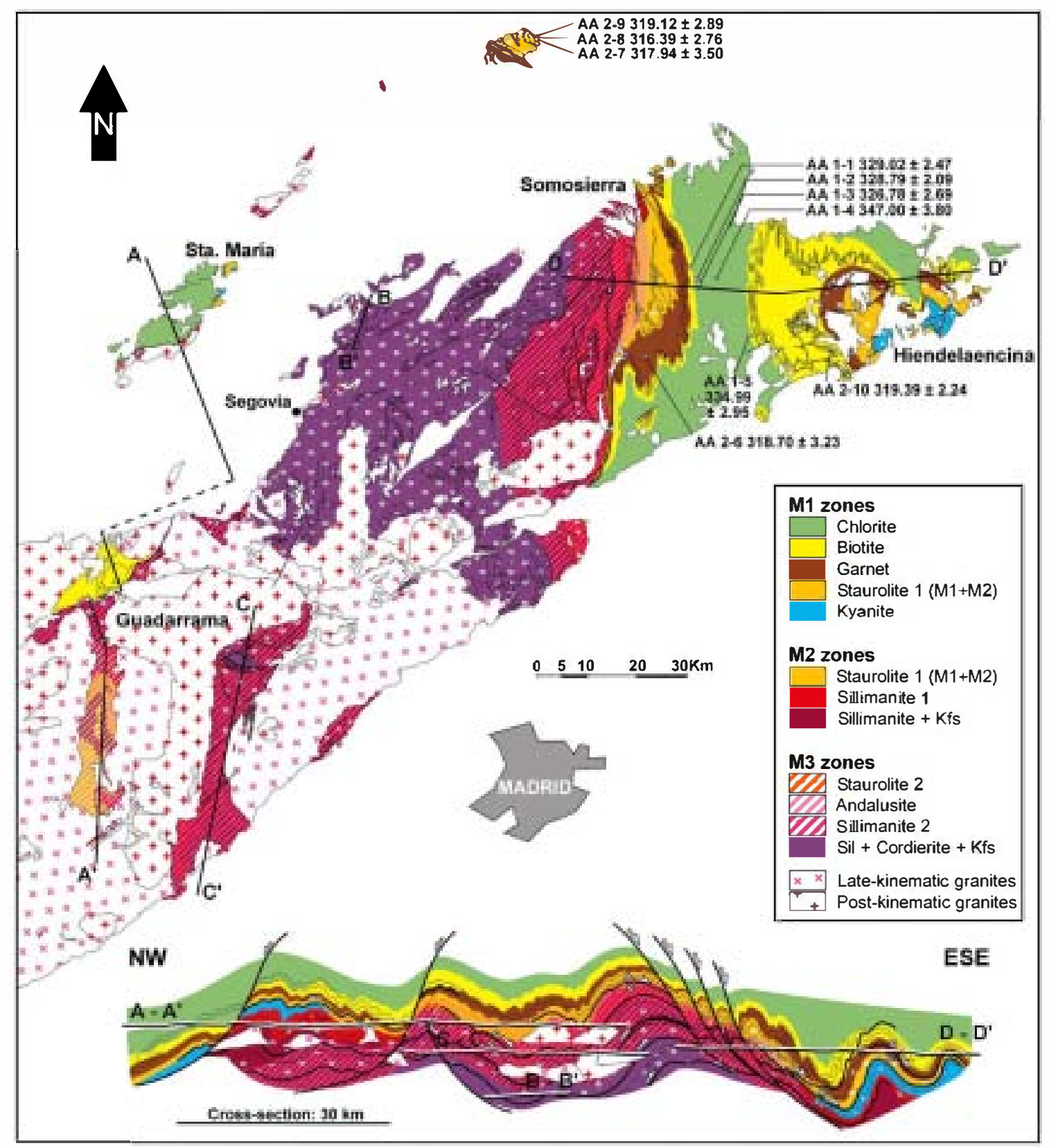

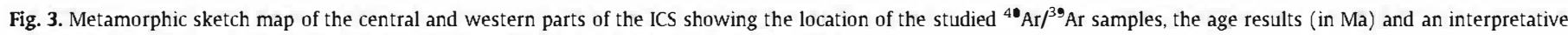
composite cross-section. White circles represent augen gneisses and white dots, leuco-gneisses.

NW

a) Santa Maria

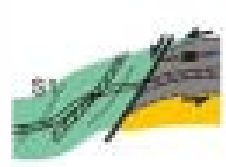

$\square$

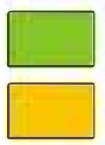

b) Guadarrama

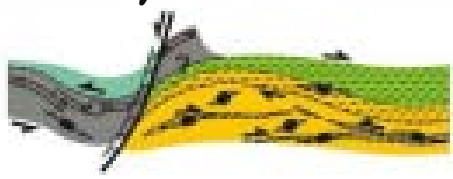

c) Somosierra

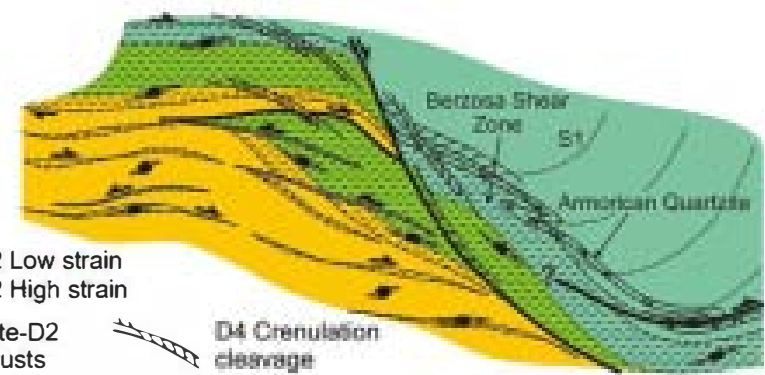

$\mathrm{S}-\mathrm{C}$ bands

$(\mathrm{D} 2, \mathrm{D} 4)$

Fig. 4. Simplified cross-sections showing the main structural features in the NW (a, b) and SE (c) flanks of the ICS dome. Cross-section lines indicated in Fig. 2. 
oblique-slip displacement indicated by stretching lineations and S-C fabrics (Escuder Viruete et al., 1998; Macaya et al., 1991). Most of these structures are oriented NE-SW and N-S in and around the high grade dome structure in the study area.

\section{Metamorphic events, mineral zones and isograds}

The Upper Unit presents a syn-D1 to syn-D2 Barrovian metamorphic zonation (M1) formed by the chlorite, biotite, gamet and staurolite 1 zones (Fig. 3). The garnet isograd (M1) is slightly oblique to the stratigraphic sequence lying above the Armorican Quartzite in the Somosierra region and towards the north, but below it to the west and east of this area. Maximum burial depths during D1 are recorded by rocks located along a NNW-SSE axis, roughly parallel to large Variscan folds and main orogenic trend. The staurolite 1 isograd is even more oblique in this axial zone. Its growth (M1-M2) postdates garnet growth in the gamet zone and rises in the NW with a $25^{\circ}$ inclination towards the $\mathrm{SE}$ in relation to the stratigraphic sequence, making the gamet zone very narrow locally. We interpret this inclination as the M2 overprinting in a flank of the dome structure raised at the end of the D2 decompressive and retrograde path, when $P-T$ conditions were no longer appropriate for garnet growth. The gneiss dome and its migmatitic core are oriented approximately NE-SW, almost perpendicular to the maximum $\mathrm{D} 1$ burial axis. During M3 (syn-D3 to initial D4), a new metamorphic low-P (LP) metamorphic zonation developed close to the high grade core. Staurolite 2 , andalusite and sillimanite 2 isograds are highly oblique to M1 and M2 zones, and roughly parallel to D3 axial planes. The microtextural relationships of the M3 index minerals with respect to the S2 schistosity and $\mathrm{F} 3$ and $\mathrm{F} 4$ microfolds, and the andalusite replacement by sillimanite 2 in the S4 crenulation cleavage, also indicate a syn-D3 to syn-D4 prograde growth.

The Middle Unit was affected by intermediate $P / T$ metamorphism (M1) reaching staurolite to kyanite conditions during D1 and D2. Later low $P / T$ recrystallization (M2) produced their replacement by syn-D2 sillimanite-bearing assemblages in the Somosierra area. Farther east (Hiendelaencina region) and west (Santa María region), kyanite remained stable in its metamorphic zone (Fig. 3), instead of being replaced by sillimanite 1 . We again interpret this symmetric zonation as indicating a domal structure in the core of which higher-grade rocks underwent more rapid decompression. M3 recrystallization took place first under andalusite and then sillimanite 2 conditions in this area.

The Lower Unit was intensely recrystallized under high-T (HT) and low to intermediate- $P$ conditions during M2. Muscovite-out (Ms-out) conditions were achieved and most lithologies transformed into migmatitic gneisses, some of them with syn-D2 banded foliations. The gneisses in the upper part of the unit show distinctive coexistence of $\mathrm{K}$-feldspar (Kfs) and Ms in highly sheared bands, either as a result of incomplete consumption of muscovite or as secondary late-D2 growth of mica. In any case, the presence of muscovite seems related to decompressive cooling in the BSZ, while deeper rocks in its footwall maintained high temperatures longer.

During M3, the deepest levels of the Lower Unit developed sillimanite + cordierite $+\mathrm{Kf}$ s diatexites, but syn-D2 growth of some cordierite porphyroblasts indicates that these conditions were probably already achieved during M2. The upper part of the unit stayed inside the sillimanite 2 zone, but no under partial melting conditions. Sillimanite 2 was stable during D3 upright folding and during development of D4 low-dipping crenulation and discrete shear zones The last movements on these structures occurred under retrograde conditions (M4), producing low temperature mylonitic foliations (Escuder Viruete et al, 1998) cross-cutting the M3 zoning (Fig. 3).

\section{Mineral chemistry}

Mineral analyses for both, thermobarometric and geochronological investigation, were performed at the Universidad Complutense, Madrid, using a Jeol JXA-8900 M electron microprobe equipped with four specrometers. Operating parameters were 10 s counting time, $15 \mathrm{kV}$ accelerating voltage, $20 \mathrm{nA}$ beam current and a beam diameter between 2 and $5 \mu \mathrm{m}$. The ZAF correction procedure was used. Mineral abbreviations used are after Whitney and Evans (2010).

Lepidoblastic white micas in the $\$ 1$ cleavage of the slates from the chlorite zone present moderate to high $X_{\mathrm{pg}}(0.17-0.35)$, low $X_{\mathrm{cel}}$ $(<0.09)$ and $\mathrm{Fe} /(\mathrm{Fe}+\mathrm{Mg})$ values ranging between 0.42 and 0.65 . Lepidoblasts both in the $\mathrm{S} 1$ and $\mathrm{S} 2$ foliations of pelitic rocks from the biotite zone exhibit lower $X_{\mathrm{pg}}(0.04-0.25)$, higher $X_{\text {cel }}(0.02-0.16)$ and a wider range of $\mathrm{Fe} /(\mathrm{Fe}+\mathrm{Mg})$ values $(0.38-0.69)$. White micas from the S2 schistosity of gamet zone metapelites show two groups of $X_{\mathrm{pg}}$ contents, one of them ranging between 0.04 and 0.09 , mainly in samples from near the top of the zone, and the other between 0.22 and 0.31 . Celadonite contents range $0.03-0.14$ and $\mathrm{Fe} /(\mathrm{Fe}+\mathrm{Mg})=0.37-0.70$. Supplementary data on representative chemical analyses of white micas are listed in Appendix A (Table A1). Those from schists of the staurolite 1 zone are predominantly paragonite-rich types $\left(X_{\mathrm{pg}}=0.12-0.32\right)$, except for some compositions probably with relic origin which show $X_{\mathrm{pg}}=0.03$. Celadonite content is $<0.15$ and $\mathrm{Fe} /(\mathrm{Fe}+\mathrm{Mg})$ ratio decreases structurally downwards between 0.37 and 0.70 . In the sillimanite 1 zone, white micas present $X_{\mathrm{pg}}=0.12-0.20$, except for probably relic compositions with $X_{\mathrm{pg}}=0.01$. Celadonite content ranges between $X_{\mathrm{cel}}=0.00$ 0.15 and $\mathrm{Fe} /(\mathrm{Fe}+\mathrm{Mg})=0.33-0.50$ for the samples from the structurally upper part of the zone, while the samples from its structurally lower part show $\mathrm{Fe} /(\mathrm{Fe}+\mathrm{Mg})=0.58-0.83$. At odds with the dependence on temperature of Na-content in white mica (Guidotti, 1984), the $X_{\mathrm{pg}}$ content decreases with increasing structural depth from the chlorite zone to the upper levels of the garnet zone. This is probably due to the increasing proportion of albitic plagioclase in the rocks. In the rest of that zone and in the staurolite 1 and sillimanite 1 zones, white mica gets richer in $\mathrm{Na}$ as plagioclase becomes richer in oligoclase content.

Chlorite lepidoblasts defining the main foliation (S1, S2) and small synkinematic porphyroblasts in metapelites of the low-grade zones (chlorite, biotite and the top of the gamet zone), show $\mathrm{Fe} /(\mathrm{Fe}+\mathrm{Mg}$ ) values ranging between 0.61 and 0.64 , independent of their textural position. Chlorite lepidoblasts of the S2 schistosity in the garnet and staurolite 1 zones present lower $\mathrm{Fe} /(\mathrm{Fe}+\mathrm{Mg}$ ) ratios (0.53-0.62), due to the progressive $\mathrm{Mg}$ increase in M1 chlorite with progressive metamorphism. Primary chlorite disappears in the kyanite (M1) zone due to consumption by the KFMASH reactions: $\mathrm{St}+\mathrm{Chl}=\mathrm{Bt}+\mathrm{AlS}$ and $\mathrm{St}+$ $\mathrm{Chl}=\mathrm{Grt}+\mathrm{AlS}$. In the sillimanite 1 zone and structurally downwards, chlorites are always a product of retrograde recrystallization (M3-M4) after garnet and biotite and have high $\mathrm{Fe} /(\mathrm{Fe}+\mathrm{Mg}$ ) ratios (0.73-0.87).

Mineral chemistry of the biotites is similar to that of the chlorites. Representative chemical analyses of biotites are included as supplementary data (Table A2). Lepidoblastic biotites in S1 and S2 foliations and syn to post-D2 porphyroblasts tend to be richer in $\mathrm{Mg}$ with increasing structural depth, except for biotites from the lowermost structural levels, whose composition reflects some retrograde re-equilibration. Ratios in $\mathrm{Fe} /(\mathrm{Fe}+\mathrm{Mg})$ equal $0.62-0.72$ in the M1 biotite zone, $0.56-0.69$ in the M1 garnet zone, $0.53-0.68$ in the M1-M2 staurolite 1 zone, 0.49-0.79 in the M2 sillimanite 1 zone and $0.50-0.74$ in the M2 sillimanite $+\mathrm{Kf} s$ zone. Individual chemical zonings respond to the same evolution. Biotite porphyroblasts show from core to rim an initial $\mathrm{Mg} / \mathrm{Fe}$ increase (M1) followed by a decrease (M2) and a final increase (M3), although some prophyroblasts from the Sil $+\mathbf{K f s}$ zone can exhibit an even later decrease related to final retrograde re-equilibration (M4).

Porphyroblastic syn-D2 plagioclases in pelitic rocks from the garnet and staurolite 1 metamorphic zones present albitic to acid oligoclase compositions ( $X_{\mathrm{an}}=0.02-0.14$ ). Porphyroblastic and granoblastic plagioclases of schists and metasedimentary gneisses from the sillimanite 1 and sillimanite $+\mathrm{Kf}$ s zones are oligoclases with some albitic compositions $\left(X_{\mathrm{an}}=0.06-0.27\right)$. The chemically most complex zoned crystals show, from core to rim, an initial increase in $\mathrm{CaO}$, probably related to the M1 prograde evolution, followed by an increase in albite (M2) 
anda final anorthite increase near the rim (M3). Representative chemical analyses of plagioclases can be found in the supplementary data (Table A3).

Three types of syn-D1-D2 garnet porphyroblasts can be distinguished according to their chemical zoning. Representative chemical analyses of garnets are found in the supplementary data (Table A4). A-type garnets are typical from the Upper and Middle units (M1 garnet zone, M1-M2 staurolite 1 zone and M2 sillimanite 1 zone). Their compositions range $X_{\mathrm{alm}}=0.64-0.88, X_{\mathrm{sps}}=0.00-0.22, X_{\mathrm{grs}}=0.01-0.20$ and $X_{\mathrm{prp}}=0.02-0.16$. The most complete profiles of chemical zoning (Fig. Sa) reflect growth zoning (Tracy, 1982) in prograde conditions (M1), with some initial $X_{\mathrm{grs}}$ increase during D1 thickening followed by decompression (initial D2). Small $X_{\text {grs }}$ increments are typical before the end of growth and could be related to pressure increase by the emplacement of the late D2 nappes. B-type gamets are only present in rocks from the top of the Lower Unit, that is, at the base of the BSZ (top of the Sil $+\mathrm{Kfs}$ zone). Their compositions range $X_{\mathrm{alm}}=0.56-0.70$, $X_{\text {sps }}=0.11-0.32, X_{\text {grs }}=0.03-0.05$ and $X_{\text {prp }}=0.07-0.16$. These gamets are characterized by complex zoning profiles (Fig. $5 b$ ) that we interpret as developed during two phases of normal growth separated by a retrograde and decompressive event, and a final retrograde rim zoning due to volume diffusion. The first retrograde event was probably generated during the final syn-D2 cooling of the BSZ, and that of the rim as the effect of nearby D4 shear bands. C-type gamets are typical in most of the Lower Unit lithologies (Sil + Kfs zone), and exhibit smooth chemical zoning profiles due to high temperature homogenization (Tracy, 1982), (Fig. 5c). Their compositions range $X_{\mathrm{alm}}=0.70-0.89$, $X_{\mathrm{sps}}=0.00-0.06, X_{\mathrm{grs}}=0.02-0.09$ and $X_{\mathrm{prp}}=0.04-0.22$. They can also present an $X_{\text {grs }}$ increase towards the rim, which can be interpreted in the same way as in A-type gamets.

Chloritoid compositions are moderately rich in $\mathrm{Fe}$, with $\mathrm{Fe} /$ $(\mathrm{Fe}+\mathrm{Mg})=0.83-0.87$. Chemical analysis of chloritoid used in thermobarometry is listed in the supplementary data (Table A5).

Syn-D1-D2 staurolite 1 porphyroblasts (M1-M2) are moderately $\mathrm{Mg}$-rich $\mathrm{Fe}$-staurolites with $\mathrm{Fe} /(\mathrm{Fe}+\mathrm{Mg})$ ranging between 0.78 and 0.88 and roughly decreasing with structural depth, which could be interpreted as an effect of $\mathrm{Fe} / \mathrm{Mg}$ partitioning between garnet and staurolite with increasing temperature. Representative chemical analyses of staurolites 1 are included in the supplementary data (Table AS). Syn-D3-D4 (M3) new porphyroblasts of staurolite 2 and overgrown rims on staurolite 1 porphyroblasts are Mg-poorer types $(\mathrm{Fe} /(\mathrm{Fe}+\mathrm{Mg})=0.87-0.92)$, which is probably related to retrograde gamet consumption through reaction $\mathrm{Grt}+\mathrm{AlS}=\mathrm{St}+\mathrm{Qz}$ and to the stability dependence of the $\mathrm{Mg}$ end-member on pressure.

Ilmenite appears as elongated crystals in the S1 and S2 foliations. It is progressively transformed into rutile at metamorphic grade higher than the biotite zone conditions. All the analyzed crystals are Fe-rich ilmenites with minor $\mathrm{MnTiO}_{3}$ content and some $\mathrm{TiO}_{2}$ excess. Chemical analyses of ilmenites used in thermobarometry are listed in the supplementary data (Table A6).

\section{6. ${ }^{40} \mathrm{Ar} /{ }^{39} \mathrm{Ar}$ geochronology}

In order to constrain the ages of the main thickening (D1) and exhumation (D2) episodes, five slates with S1 foliation have been sampled from the chlorite and biotite zones, as well as five slates and schists from the biotite and garnet zones, the latter with $\mathrm{S} 2$ as the main foliation. Both groups of samples (see Fig. 3 for location) were obtained from the upper part of their respective structural levels, which are supposed to cool earlier and closer in time to the age of the respective tectonic process, preventing thermally induced argon diffusion (House and Hodges, 1994; Vance et al, 1998). For the same reason, the samples were taken far away from any possible M3 overprinting effect and only those without latter crenulationswere selected to avoid intra-crystalline defect-enhanced diffusion in white micas (Hames and Cheney, 1997; Kramar et al., 2001; Lee, 1995; Mulch et al., 2002). For analytical techniques (Koppers, 2002; Koppers et al., 2000; lips et al., 1998; Wijbrans et al., 1995), see supplementary data at Appendix B.

\subsection{Sample description}

AA 1-1 Middle Ordovician black slate from the M1 biotite metamorphic zone, $1500 \mathrm{~m}$ structurally above the Armorican Quartzite. It is formed by white mica, quartz, chlorite, ilmenite and some graphite. The rock shows a fine-grained S1 slaty cleavage defined by the orientation of the planar minerals.

AA 1-2 Dark gray slate from the Middle Ordovician series sampled some $2800 \mathrm{~m}$ above the Armorican Quartzite, in the M1 chlorite metamorphic zone. It consists of white mica, quartz, ilmenite, chlorite, and some graphite in a well-developed, fine grained S1 slaty cleavage foliation.

AA 1-3 Gray slate from the Middle Ordovician sequence, $3000 \mathrm{~m}$ above the Armorican Quartzite, in the M1 chlorite zone. S1 foliation is a very fine-grained slaty cleavage formed by white mica, quartz and some chlorite and ilmenite.

AA 1-4 Gray slate from the Middle Ordovician sequence, structurally $6000 \mathrm{~m}$ above the Armorican Quartzite, in the M1 metamorphic zone of chlorite. S1 slaty cleavage is formed by white mica, quartz, stilpnomelane and ilmenite. Some rounded clastic grains of chloritized biotite are also present.

AA 1-5 Gray slate from the Early-Middle Ordovician transition, collected $300 \mathrm{~m}$ above the Armorican Quartzite, approximately on the (a)

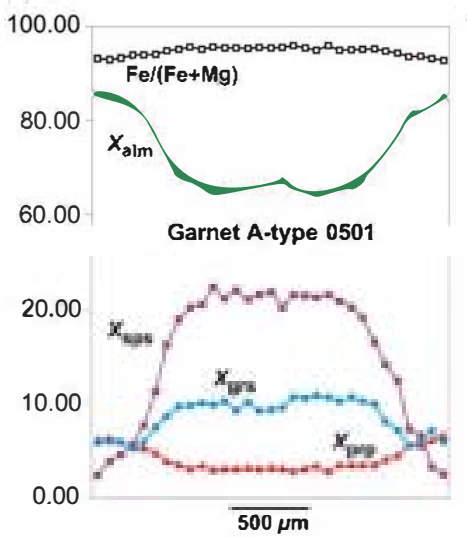

(b)
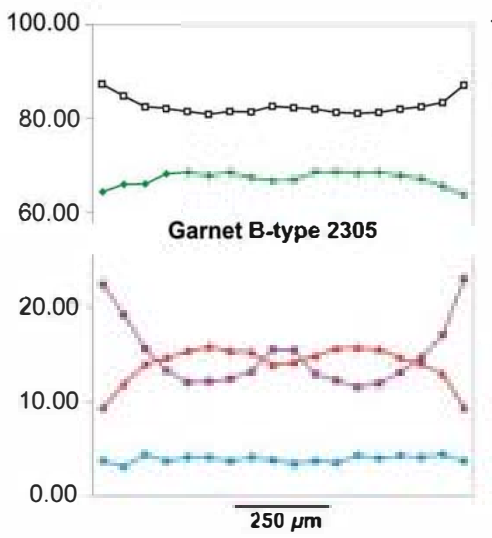

(c)
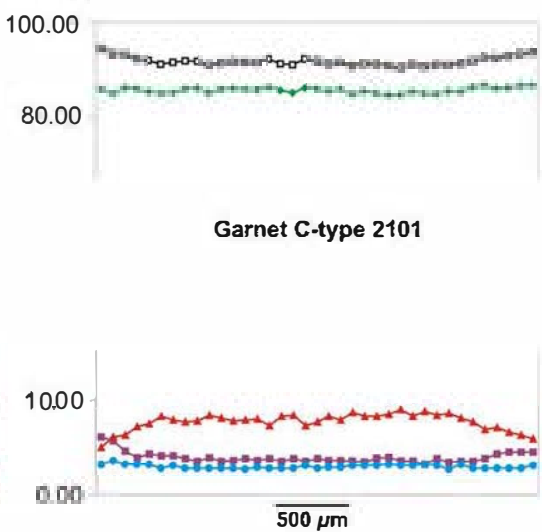

Fig. 5. Chemical zoning of three garnets representative of the different types described in the text. (a) A-type. (b) B-type. (c) C-type. 
biotite M1 isograd. The tectonic fabric is a S1 slaty cleavage formed by white mica, quartz, stilpnomelane, chlorite and ilmenite.

AA 2-6 Dark gray phyllite from the Early Ordovician sequence, sampled some hundreds of meters below the Armorican Quartzite, in the M1 gamet zone. It is composed of quartz, white mica, some small gamet porphyroblasts and lepidoblastic biotite. Foliation is a well developed S2 schistosity where lepidoblastic micas in the matrix are surrounding the euhedral gamet crystals.

AA 2-7 Reddish-black slate from the Early-Middle Ordovician transition, sampled just above the Armorican quartzite, in M1 biotite zone conditions. It consists of white mica, quartz, ilmenite and some chlorite and graphite, with a well developed S2 slaty cleavage.

AA 2-8 Gray slate from the Early-Middle Ordovician transition, a few meters above AA 2-7 location in the M1 biotite zone. The S2 fabric is a slaty cleavage formed by white mica lepidoblasts, quartz and some ilmenite and chlorite.

AA 2-9 Gray phyllite from the Early-Middle Ordovician transition, collected in the M1 biotite zone, some tens of meters above AA 2-8 location. It is a white mica-rich metapelite with some quartz, ilmenite and chlorite forming a thin but well developed S2 schistosity.

AA 2-10 Light gray phyllite from the Early Ordovician series near the Armorican Quartzite, in a shear zone affecting an overturned fold limb. Metamorphic conditions are those of M1 biotite zone. It is only formed by white mica, quartz and ilmenite. The main S2 foliation is a well developed crenulation cleavage, including a few oriented micas inside thin quartz-rich domains which are interpreted as relict S1. Intersection criteria indicate D2 top-to-the E shear sense.

\subsection{Results}

All the obtained ages properly correspond to pseudo plateau ages with high MSWD values (Table 1), what is likely to expect from experiments with Variscan slates. However, no significant old apparent ages appear at the beginning or end of the heating experiments which could be linked to important excess argon, and released ${ }^{39} \mathrm{Ar}$ in the plateau steps is always $>90 \%$. Their high $\mathrm{K} / \mathrm{Ca}$ ratios are indicative of the white mica enriched nature of the samples, but variations along heating steps in most of the samples point to some mixture of Ar source phases in the rock grains, probably as minor rests of chlorite and plagioclase. However, stepwise heating of the $S 1$ samples (Fig. 6) yield ${ }^{39} \mathrm{Ar}$ diffusion gradients with very slight upward-convex spectra, so no important mixture of different white mica populations is expected (Wijbrans and McDougall, 1986).

The variation between pseudo plateau ages of the samples AA 1-1 $(329.02 \pm 2.47 \mathrm{Ma})$, AA $1-2(328.79 \pm 2.09)$, AA $1-3(326.78 \pm 2.69)$, AA $1-4(347.00 \pm 3.80 \mathrm{Ma})$ and AA $1-5(334.99 \pm 2.95 \mathrm{Ma})$, is interpreted as owing to a long cooling history of the upper structural levels above the D2 shear zone and only the 347 Ma age could be considered close to the syn-D1 crystallization age. Ar-loss ages as old as 354 and $353 \mathrm{Ma}$ obtained in the incremental heating of AA 1-4, which is the structurally uppermost dated sample, may be tentatively taken as an initial reference age. The ages on monazites of medium to high grade rocks with $\mathrm{S} 2$ foliation from this same area coincide with the younger part of this time span (337-326 Ma; U-Pb by TIMS) which Escuder Viruete et al. (1998) interpreted as the beginning of cooling close to the thermal peak of the rocks in the D2 shear zone.

Stepwise heating of samples with pervasive S2 schistosity shows a clearer upward-convex spectra (Fig. 7), though it is slight enough to be considered not significant. Pseudo plateau ages yield $319.39 \pm$ $2.24 \mathrm{Ma}$ (AA 2-10), 319.12 $\pm 2.89 \mathrm{Ma}$ (AA 2-9), 318.70 $\pm 3.23 \mathrm{Ma}$ (AA 2-6), 317.94 $\pm 3.50 \mathrm{Ma}$ (AA 2-7) and $316.39 \pm 2.76 \mathrm{Ma}$ (AA 2-8). The low dispersion of results also points to a single and rapid syn-D2 episode of complete recrystallization of the white micas, close to the closure temperature of $350 \pm 30^{\circ} \mathrm{C}$ (Lips, 1998; McDougall and Harrison, 1999), initiated around $327 \mathrm{Ma}$ and finished at c. 316 Ma. All the samples correspond to the upper part of the BSZ except sample AA2-10, which corresponds to an E-directed thrust affecting a section of the Upper Unit and which could be related to other, more internal late-D2 thrusts. Systematic ages between 290 and 313 Ma obtained in the first and last steps of incremental heating could be due to moderate rejuvenation by Ar-loss episodes related to the intrusion of Variscan granitoids.

\section{Thermobarometry}

Pelitic and semipelitic rock samples from the garnet, staurolite 1, sillimanite 1 and sillimanite + Kfs metamorphic zones were analyzed by electron microprobe for mineral chemistry study and thermobarometric calculations using avPT mode of THERMOCALC 3.21 (Holland and Powell, 1985, 1990; Powell and Holland, 1985, 1988) on the mineral compositions which are supposed to correspond to the metamorphic peak conditions (Table 2). Phase end-member activities were calculated using the AX program (Holland and Powell, 1990). Garnet follows a 2-site mixing model with ferric iron estimation on the basis of cations $=8$ for 12 oxygens. Plagioclase is after model 1 in Holland and Powell (1992), all iron as ferric. Ferric iron in Al-M1 ordered biotite is calculated upon tetraedric + octaedric cations $=6.9$ for 11 oxygens, with a maximum allowed ratio $R_{\max }=0.15$. The mixing model of white mica is from Holland and Powell (1998), with ferric iron estimation on tetraedric + octaedric cations $=6.05$ for 11 oxygens and $R_{\max }=0.7$. A 4-site ideal mixing model, all ferrous assumed, is used in staurolite. Chloritoid is calculated following a 2-site mixing model with ferric iron estimated on 4 cations for 6 oxygens and $R_{\max }=0.2$. Ilmenite uses a 2 -site ideal mixing model with ferric iron on 2 cations for 3 oxygens. P-T-t paths (Fig. 8) were drawn according to gamet chemical zonings, microtextural relationships and the petrogenetic grid for metapelites after Holland and Powell (1998), which is not shown for clarity.

Four samples of schists from the structurally lower part of the M1 garnet zone were used for thermobarometric calculations. The garnet compositions used in the considered mineral assemblages (Table A4) correspond to those of lower $\mathrm{Fe} /(\mathrm{Fe}+\mathrm{Mg})$ ratio, which are found

Table 1

Summary of ${ }^{4 \bullet} \mathrm{Ar} /{ }^{39} \mathrm{Ar}$ dating results.

\begin{tabular}{|c|c|c|c|c|c|c|c|}
\hline Sample & Rock & Foliation & Metamorphic zone & Apparent total gas age (Ma, $2 \sigma$ ) & Plateau age (Ma, $2 \sigma$ ) & WSMD & $\%^{39} \mathrm{Ar}$ (in plateau) \\
\hline AA $1-1$ & Slate & $\mathrm{S} 1$ & M1 biotite & $330.18 \pm 2.01$ & $329.02 \pm 2.47$ & 8.50 & 99.57 \\
\hline AA $1-2$ & Slate & S1 & M1 chlorite & $328.80 \pm 1.90$ & $328.79 \pm 2.09$ & 4.12 & $\mathbf{9 2 . 3 2}$ \\
\hline AA 1-3 & Slate & $\mathrm{S} 1$ & M1 chlorite & $325.72 \pm 1.89$ & $326.78 \pm 2.69$ & 13.91 & 99.40 \\
\hline AA $1-4$ & Slate & $\mathrm{S} 1$ & M1 chlorite & $343.81 \pm 2.04$ & $347.00 \pm 3.80$ & 29.86 & 99.30 \\
\hline AA $1-5$ & Slate & $\mathrm{S} 1$ & M1 biotite & $335.17 \pm 1.99$ & $334.99 \pm 2.95$ & 15.69 & 100.00 \\
\hline AA 2-6 & Phyllite & $\mathrm{S} 2$ & M1 garnet & $323.55 \pm 1.98$ & $318.70 \pm 3.23$ & 25.08 & 100.00 \\
\hline AA 2-7 & Slate & $\mathrm{S} 2$ & M1 biotite & $321.25 \pm 1.95$ & $317.94 \pm 3.50$ & 26.79 & 98.83 \\
\hline AA 2-8 & Slate & $\mathrm{S} 2$ & M1 biotite & $319.59 \pm 1.94$ & $316.39 \pm 2.76$ & 16.86 & 100.00 \\
\hline AA 2-9 & Phyllite & $\mathrm{S} 2$ & M1 biotite & $321.25 \pm 1.93$ & $319.12 \pm 2.89$ & 16.98 & 96.63 \\
\hline AA $2-10$ & Phyllite & $\mathrm{S} 2$ & M1 biotite & $320.52 \pm 1.90$ & $319.39 \pm 2.24$ & 7.30 & 100.00 \\
\hline
\end{tabular}



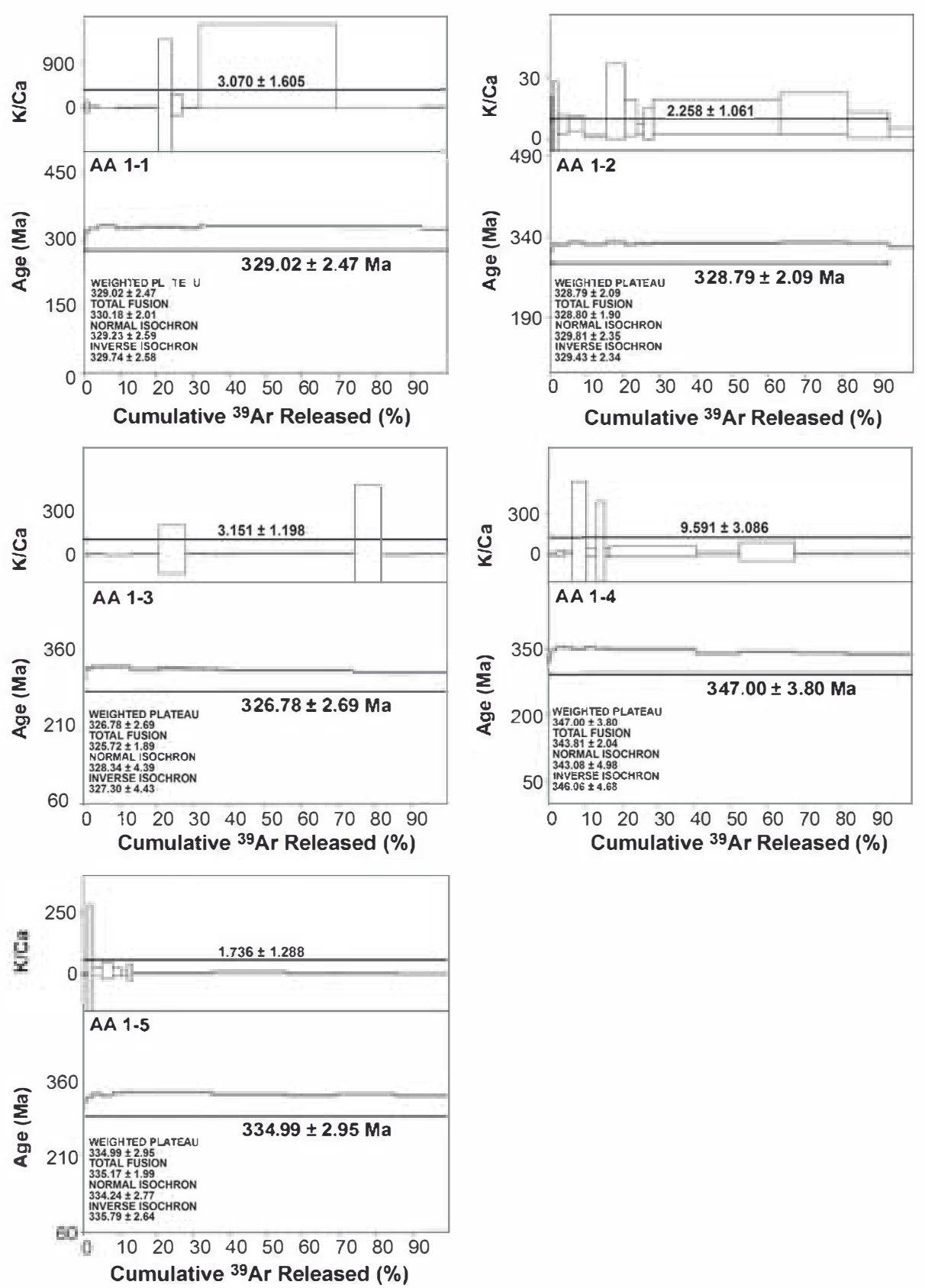

Fig. 6. Incremental heating ${ }^{4 \bullet} \mathrm{Ar} /{ }^{39} \mathrm{Ar}$ ages and pseudo-plateaux in white mica-enriched fractions from metapelites with $\mathrm{S} 1$ foliation.

near the rims of the A-type, syn-D2 porphyroblasts. Core compositions of lepidoblastic syn-D2 muscovite (Table A1) and biotite, or the core composition of syn-D2 deformed biotite porphyroblasts were also used (Table A2). When plagioclase was present, compositions with higher $X_{\text {an }}$ values were used (Table A3), as this composition is considered to represent the syn-D2 final M1 conditions. Ilmenite (Table A6) was always present as $S 2$ oriented flakes. $P-T$ results from the samples are listed in Table 2. Average conditions are $7.2 \pm 1.6 \mathrm{kbar}$ and $494 \pm 71{ }^{\circ} \mathrm{C}$.

Another four samples of schists from the structurally upper part of the M1-M2 staurolite 1 zone and two samples from its lower part were also used. A-type garnet, muscovite, biotite, plagioclase (when present) and ilmenite compositions were selected following the same criteria as for samples from the gamet zone. Near rim composition of chloritoid and core (M1) compositions of staurolite 1 were used in some samples (Table A5). Pure $\mathrm{TiO}_{2}$ ideal compositions were used for rutile when this mineral is present in the rocks. The average results for the samples from the top of the staurolite 1 zone are $8.1 \pm 1.8 \mathrm{kbar}$ and $615 \pm$ $56{ }^{\circ} \mathrm{C}$; and those for the samples from near its base are $8.9 \pm 1.2$ and $658 \pm 577^{\circ} \mathrm{C}$.

In the M2 sillimanite 1 zone, A-type garnet, muscovite, biotite, plagioclase, ilmenite, rutile and staurolite 1 compositions were selected following the same criteria as in garnet and staurolite 1 zones; except for C-type gamet in sample 19, which composition was taken from the low $\mathrm{Fe} /$ $(\mathrm{Fe}+\mathrm{Mg})$ homogenized core. Calculations using altematively sillimanite or kyanite led to small differences in $P-T$ conditions and they both were always projected in the kyanite stability field, so kyanite was used for final calculations. THERMOCALC estimates yielded $9.4 \pm 1.1 \mathrm{kbar}$ and $687 \pm 25^{\circ} \mathrm{C}$ for the structurally upper part of the metamorphic zone and $8.4 \pm 1.1 \mathrm{kbar}$ and $676 \pm 26^{\circ} \mathrm{C}$ for the lower one.

For the M2 sillimanite $+\mathrm{Kf}$ s zone, two samples from near its top were used and another two from near the M3 sillimanite + cordierite $+\mathrm{Kf}$ zone. The mineral association in the structurally upper part includes 

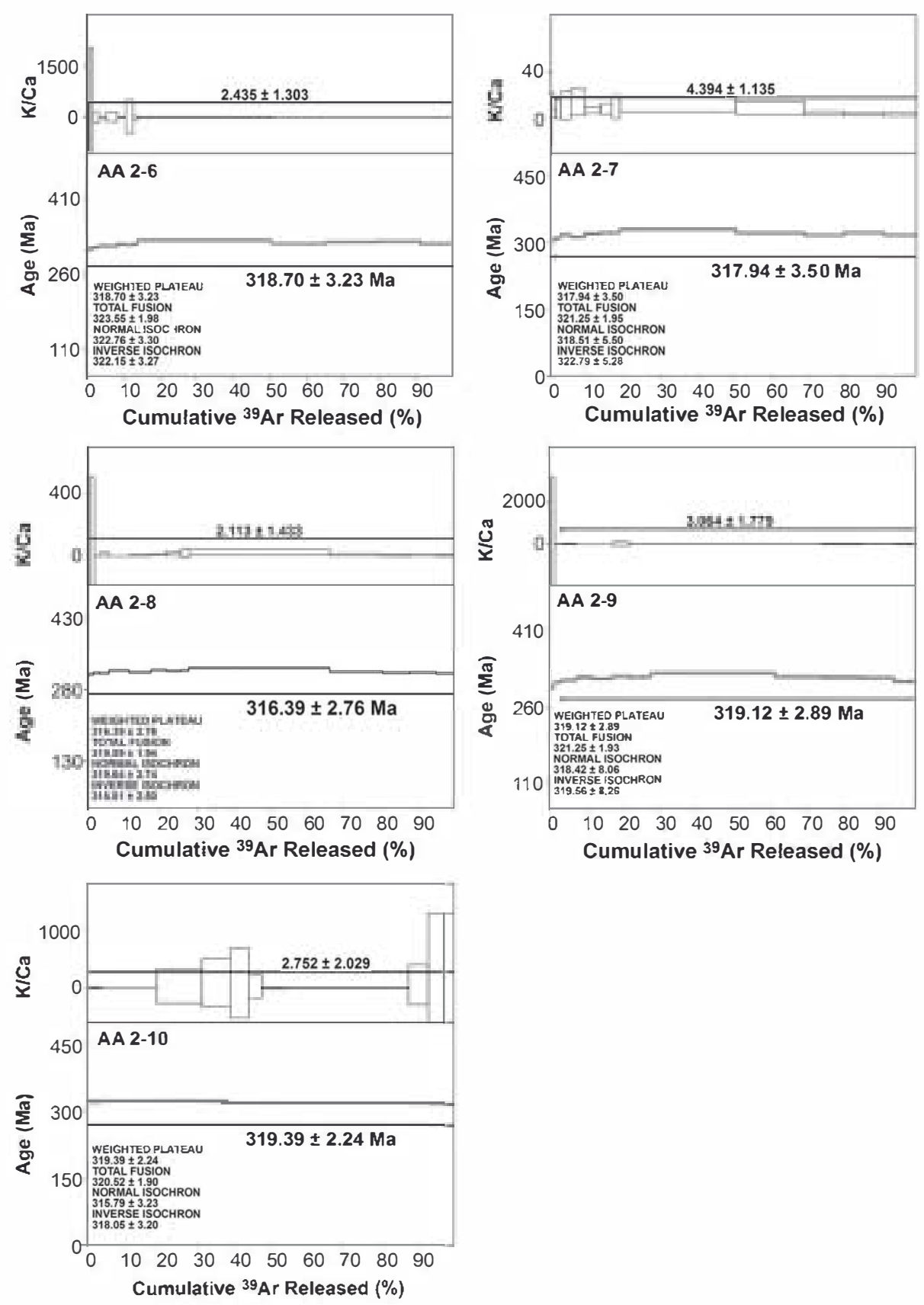

Fig. 7. Incremental heating ${ }^{4 \bullet} \mathrm{Ar} /{ }^{39} \mathrm{Ar}$ ages and pseudo-plateaux in white mica-enriched fractions from metapelites with S2 foliation.

B-type garnet, which near rim lower $\mathrm{Fe} / \mathrm{Mg}$ composition was taken. Near rim compositions of granoblastic biotites, ilmenites and plagioclases were also used, together with pure compositions for rutile and sillimanite, and core compositions of $\mathbf{S 2}$ oriented muscovites, which are supposed to be new late-D2 lepidoblasts formed just after partial melting reaction to produce Sil $+\mathrm{Kf}$. THERMOCALC yielded conditions around $5.9 \pm$ $1.4 \mathrm{kbar}$ and $659 \pm 105^{\circ} \mathrm{C}$. In the higher metamorphic grade part, homogenized core compositions of C-type garnet were used together with high $X_{\text {an }}$ plagioclase and low $\mathrm{Fe} / \mathrm{Mg}$ biotite compositions, analyzed ilmenites and pure stoichiometric rutile and sillimanite. The calculated conditions are around $7.5 \pm 1.6 \mathrm{kbar}$ and $746 \pm 94{ }^{\circ} \mathrm{C}$.

$P-T$ conditions of the sillimanite $+K f$ s zone and the higher grade part of the sillimanite 1 zone are lower than those of the rocks structurally just above. This is interpreted as an effect of diachronism in the equilibrium from M1 to M2 and between the different M2 associations along the decompressive and retrograde late-D2 path of the rocks.

\section{8. $P$ - T-t paths}

The evolution of the crustal section, as derived from the P-T-t paths, shows a complex succession of processes (Fig. 8). The ages of S1 fabrics ranging 354-347 Ma probably correspond to D1 thickening in this area. Maximum pressures achieved during D1 thickening had to be somewhat higher than $P_{T \max }$ calculated for peak conditions in garnet, staurolite 1 and sillimanite 1 zones rocks, as the A-type garnet compositions used are those of near rim lower $\mathrm{Fe} / \mathrm{Mg}$ ratio instead of those with higher $X_{\text {grs }}$ values found in the garnet cores. The pressure conditions calculated for the rocks from the garnet zone yield around $7 \mathrm{kbar}$ at the Armorican Quartzite level during initial D2. The Upper Unit above the Armorican Quartzite is only $6 \mathrm{~km}$ thick and F1 folds are scarce. This implies a burial depth at least $12-15 \mathrm{~km}$ larger than D1 could produce by its own, even considering a $50 \%$ of thickening. Around a $70 \%$ of thickness can be explained by the emplacement of 
Table 2

Resume of mineral associations and thermobarometric results.

\begin{tabular}{|c|c|c|c|c|c|c|c|c|c|}
\hline \multirow[b]{2}{*}{ Metamorphic zone } & & \multirow[b]{2}{*}{ Sample } & \multirow[b]{2}{*}{ Mineral paragenesis } & \multirow[b]{2}{*}{$\mathrm{P}$ (Kbar) } & \multirow[b]{2}{*}{$\mathrm{T}\left({ }^{*} \mathrm{C}\right)$} & \multirow[b]{2}{*}{ Corr. } & \multicolumn{3}{|c|}{ Average values $(\sigma=1)$} \\
\hline & & & & & & & $\mathrm{P}$ (Kbar) & $\mathrm{T}\left({ }^{\circ} \mathrm{C}\right)$ & Corr. \\
\hline \multirow[t]{4}{*}{ M1 garnet } & & 07 & $\mathrm{Bt}+\mathrm{Ms}+\mathrm{Grt}(\mathrm{A})+\mathrm{Ilm}+\mathrm{Qz}$ & $7.5 \pm 1.4$ & $491 \pm 69$ & 0.213 & & & \\
\hline & & 08 & $\mathrm{Bt}+\mathrm{Ms}+\mathrm{Grt}(\mathrm{A})+\mathrm{Ilm}+\mathrm{Qz}$ & $7.6 \pm 2.3$ & $487 \pm 90$ & 0.110 & & & \\
\hline & Base & 25 & $\mathrm{Bt}+\mathrm{Ms}+\mathrm{Grt}(\mathrm{A})+\mathrm{PI}+\mathrm{Il} \mathrm{m}+\mathrm{Qz}$ & $7.7 \pm 1.5$ & $511 \pm 63$ & 0.611 & $7.2 \pm 1.6$ & $494 \pm 71$ & 0.428 \\
\hline & & 26 & $\mathrm{Bt}+\mathrm{Ms}+\mathrm{Grt}(\mathrm{A})+\mathrm{PI}+\mathrm{Il} \mathrm{m}+\mathrm{Qz}$ & $6.0 \pm 1.1$ & $488 \pm 62$ & 0.777 & & & \\
\hline \multirow[t]{6}{*}{ M1-M2 staurolite 1} & Top & 09 & $\mathrm{Bt}+\mathrm{Ms}+\mathrm{Grt}(\mathrm{A})+\mathrm{St}+\mathrm{Il} \mathrm{m}+\mathrm{Qz}$ & $8.2 \pm 1.7$ & $612 \pm 60$ & -0.264 & & & \\
\hline & & 10 & $\mathrm{Bt}+\mathrm{Ms}+\mathrm{Grt}(\mathrm{A})+\mathrm{St}+\mathrm{Rt}+\mathrm{Il} \mathrm{m}+\mathrm{Qz}$ & $8.7 \pm 2.0$ & $673 \pm 74$ & -0.365 & & & \\
\hline & & 11 & $\mathrm{Bt}+\mathrm{Ms}+\mathrm{Grt}(\mathrm{A})+\mathrm{St}+\mathrm{Rt}+\mathrm{Il} \mathrm{m}+\mathrm{Qz}$ & $6.6 \pm 1.7$ & $574 \pm 58$ & -0.323 & $8.1 \pm 1.8$ & $615 \pm 56$ & -0.177 \\
\hline & & 12 & $\mathrm{Bt}+\mathrm{Ms}+\mathrm{Grt}(\mathrm{A})+\mathrm{St}+\mathrm{Ctd}+\mathrm{Rt}+\mathrm{Il} \mathrm{m}+\mathrm{Qz}$ & $9.0 \pm 1.9$ & $601 \pm 31$ & 0.246 & & & \\
\hline & Base & 13 & $\mathrm{Bt}+\mathrm{Ms}+\mathrm{Grt}(\mathrm{A})+\mathrm{St}+\mathrm{PI}+\mathrm{Rt}+\mathrm{Ilm}+\mathrm{Qz}$ & $8.8 \pm 1.2$ & $666 \pm 57$ & 0.523 & $8.9 \pm 1.2$ & $658 \pm 57$ & 0.587 \\
\hline & & 14 & $\mathrm{Bt}+\mathrm{Ms}+\mathrm{Grt}(\mathrm{A})+\mathrm{St}+\mathrm{PI}+\mathrm{Rt}+\mathrm{Ilm}+\mathrm{Qz}$ & $9.0 \pm 1.2$ & $649 \pm 57$ & 0.650 & & & \\
\hline \multirow[t]{5}{*}{ M2 sillimanite 1 (M1 kyanite) } & Top & 15 & $\mathrm{Bt}+\mathrm{Ms}+\mathrm{Grt}(\mathrm{A})+\mathrm{St}+\mathrm{Ky}+\mathrm{PI}+\mathrm{Rt}+\mathrm{Ilm}+\mathrm{Qz}$ & $9.8 \pm 1.2$ & $699 \pm 29$ & 0.907 & $\mathbf{9 . 4} \pm 1.1$ & $687 \pm 25$ & 0.865 \\
\hline & & 16 & $\mathrm{Bt}+\mathrm{Ms}+\mathrm{Grt}(\mathrm{A})+\mathrm{St}+\mathrm{Ky}+\mathrm{PI}+\mathrm{Rt}+\mathrm{Ilm}+\mathrm{Qz}$ & $8.8 \pm 1.1$ & $671 \pm 24$ & 0.937 & & & \\
\hline & & 17 & $\mathrm{Bt}+\mathrm{Ms}+\mathrm{Grt}(\mathrm{A})+\mathrm{Ky}+\mathrm{PI}+\mathrm{Rt}+\mathrm{Ilm}+\mathrm{Qz}$ & $\mathbf{9} .7 \pm 1.0$ & $692 \pm 22$ & 0.750 & & & \\
\hline & Base & 18 & $\mathrm{Bt}+\mathrm{Ms}+\mathrm{Grt}(\mathrm{A})+\mathrm{Ky}+\mathrm{PI}+\mathrm{Rt}+\mathrm{Ilm}+\mathrm{Qz}$ & $8.3 \pm 1.1$ & $677 \pm 23$ & 0.769 & $8.4 \pm 1.1$ & $676 \pm 26$ & 0.771 \\
\hline & & 19 & $\mathrm{Bt}+\mathrm{Ms}+\mathrm{Grt}(\mathrm{C})+\mathrm{Ky}+\mathrm{PI}+\mathrm{Rt}+\mathrm{Il} \mathrm{m}+\mathrm{Qz}$ & $8.4 \pm 1.4$ & $674 \pm 29$ & 0.773 & & & \\
\hline \multirow[t]{4}{*}{ M2 sillimanite $+\mathrm{Kfs}$} & Top & 23 & $\mathrm{Bt}+\mathrm{Grt}(\mathrm{B})+\mathrm{SiI}+\mathrm{PI}+\mathrm{Rt}+\mathrm{Ilm}+\mathrm{Qz}$ & $6.5 \pm 1.4$ & $670 \pm 105$ & 0.714 & $5.9 \pm 1.4$ & $659 \pm 105$ & 0.700 \\
\hline & & 24 & $\mathrm{Bt}+\mathrm{Grt}(\mathrm{B})+\mathrm{SiI}+\mathrm{PI}+\mathrm{Rt}+\mathrm{Il} \mathrm{m}+\mathrm{Qz}$ & $5.3 \pm 1.3$ & $648 \pm 104$ & 0.686 & & & \\
\hline & Base & 21 & $\mathrm{Bt}+\mathrm{Grt}(\mathrm{C})+\mathrm{SiI}+\mathrm{PI}+\mathrm{Rt}+\mathrm{Il} \mathrm{m}+\mathrm{Qz}$ & $7.5 \pm 1.7$ & $744 \pm 136$ & 0.788 & $7.5 \pm 1.6$ & $746 \pm 94$ & 0.488 \\
\hline & & 22 & $\mathrm{Bt}+\mathrm{Grt}(\mathrm{C})+\mathrm{SiI}+\mathrm{PI}+\mathrm{Rt}+\mathrm{Il} \mathrm{m}+\mathrm{Qz}$ & $7.5 \pm 1.5$ & $747 \pm 51$ & 0.187 & & & \\
\hline
\end{tabular}

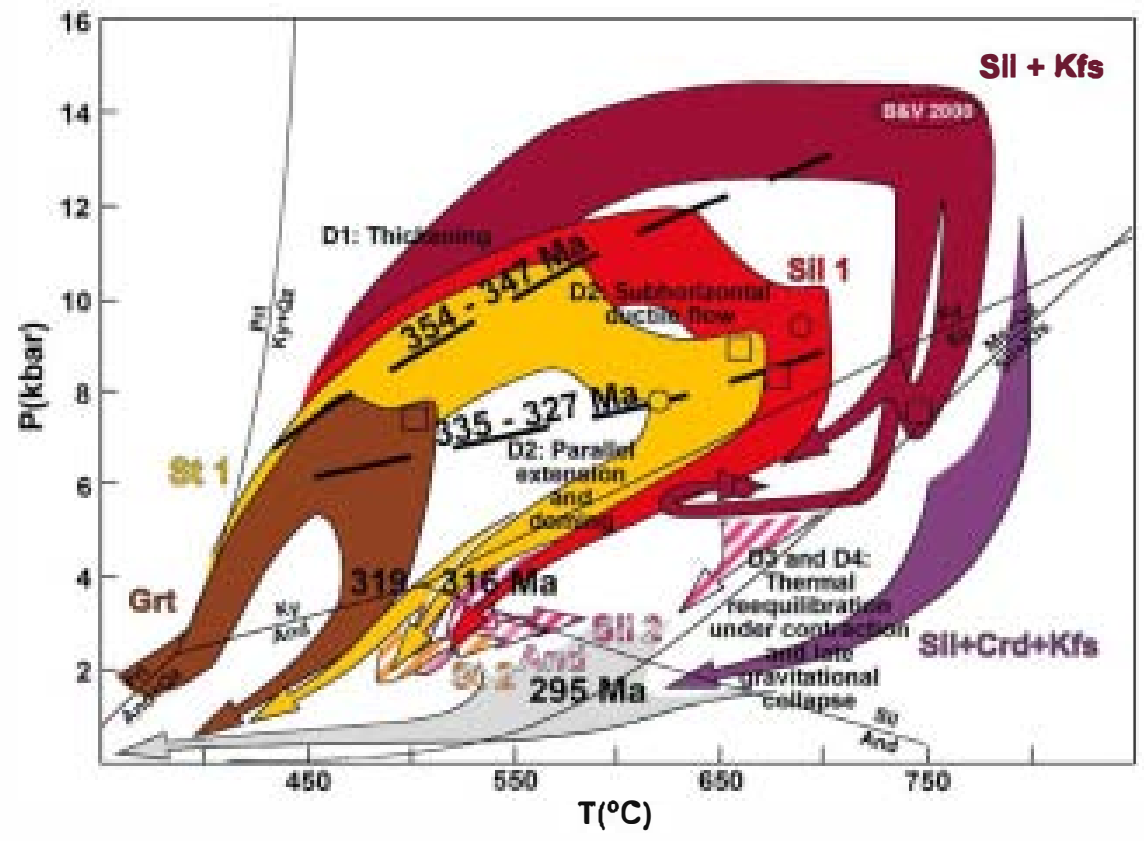

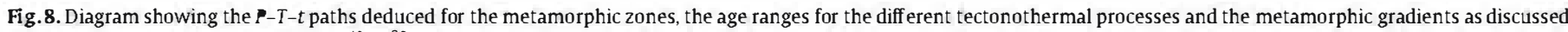

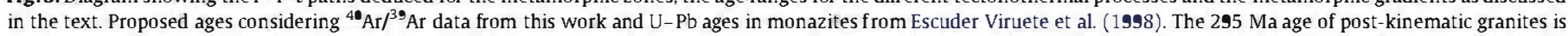

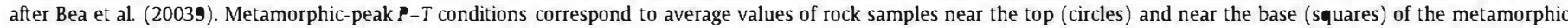

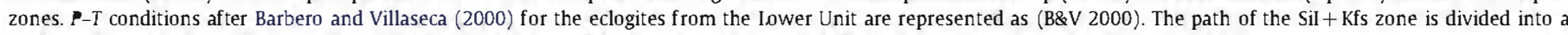
rapid cooling evolution of the top, affected by the BSZ and that of the deep levels below. Stability fields are from Holland and Powell (1998).

an allochthonous nappe and/or its correlative synorogenic deposits. This is represented by a change in the $P T$ gradient of the garnet zone path during D1. The metamorphic gradient of the upper part of the thickened crust at the end of D1, calculated on the basis of the P-T conditions of the gamet zone, is around $23{ }^{\circ} \mathrm{C} / \mathbf{l m}$; while the mean crustal gradient after the M1 $P_{\max }-T_{\max }$ conditions calculated by Barbero and
Villaseca (2000) for retroeclogite boudins found in the Lower Unit (14 kbar and $750{ }^{\circ} \mathrm{C}$ ), is around $18{ }^{\circ} \mathrm{C} / \mathrm{km}$.

However, the metamorphic field gradient in the BSZ calculated through the peak conditions of the gamet, staurolite 1 and the M1 kyanite (M2 sillimanite 1 zone) $P-T$ conditions is around $33-36{ }^{\circ} \mathrm{C} / \mathbf{l m}$, higher than the mean crustal gradient at the end of $\mathrm{D} 1$, and less than should

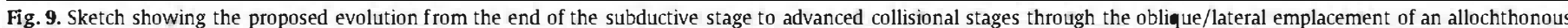

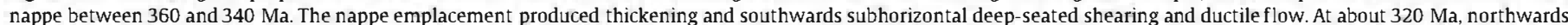

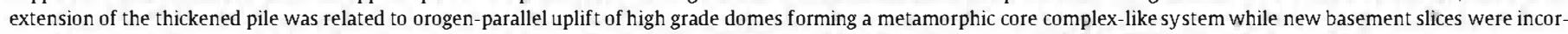
porated orthogonally by underthrusting. The structure of the south CIZ, OMZ and SPZ is modified af ter Simancas et al. (2001, 2003). Abbreviations as in Fig. 1. 

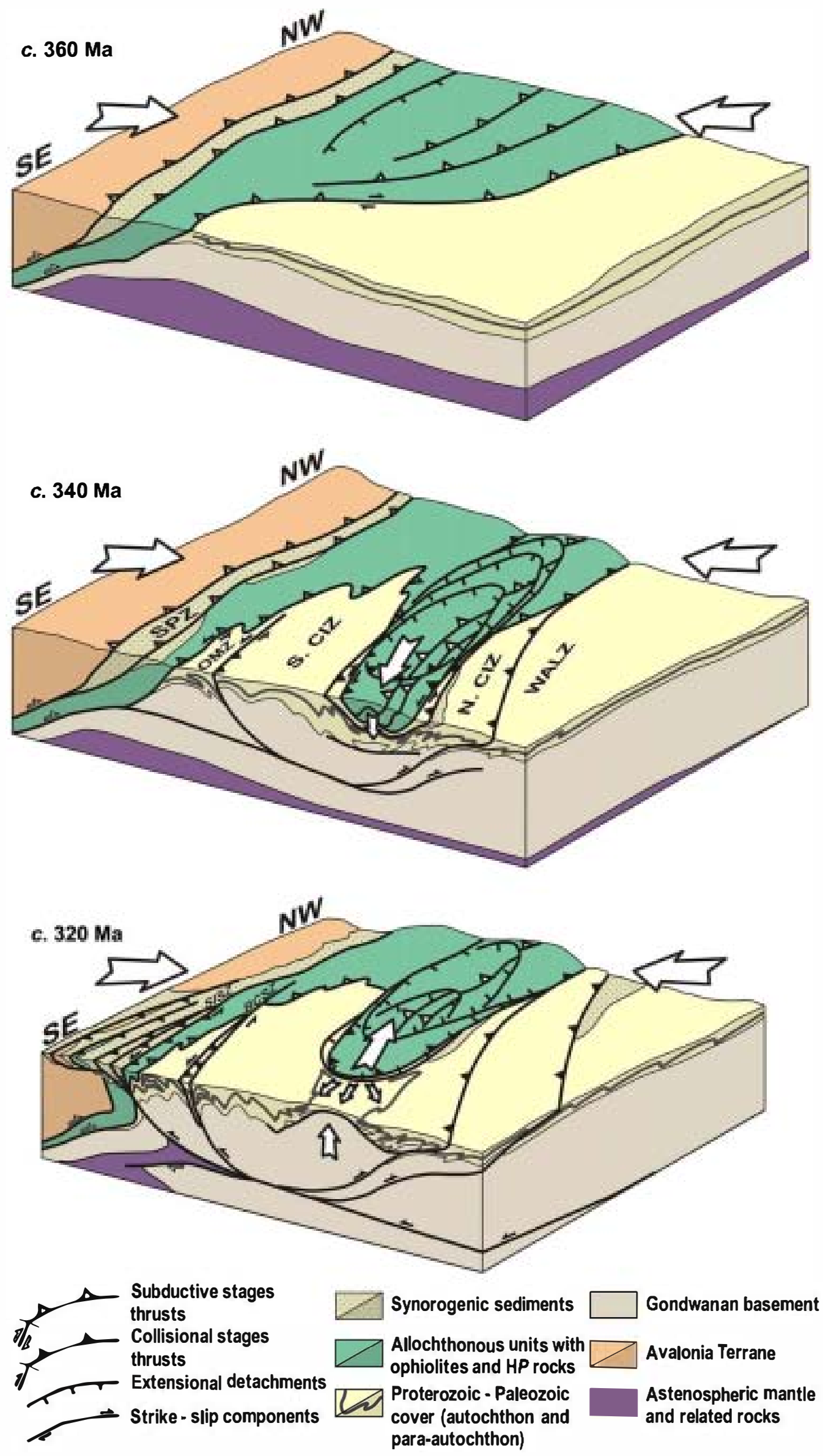
be expected for a crustal extension regime. It likely points to a ductile thinning process (Ring et al., 1999) during the initial development of the BSZ and to a top-to-the-SE directed ductile subhorizontal flow of the medium and high grade rocks during initial D2, in a similar way to the upper zone of the channel flow system proposed by Beaumont et al. (2001) for the Himalayas, but under oblique escape movement respect to the underthrusting crust. The younger S1 ages ranging between 335 and $327 \mathrm{Ma}$ are very close to the $\mathrm{U}-\mathrm{Pb}$ ages obtained in higher grade rocks with S2 foliations (Escuder Viruete et al, 1998), which suggest the resetting of the $S 1$ foliations under slow cooling in the uppermost levels while the deep-seated BSZ was developing in lower structural levels. Small $X_{\mathrm{grs}}$ diminutions accompanied by strong $\mathrm{Fe} / \mathrm{Mg}$ decays are recorded by the chemical zoning of A-type garnets, and indicate a low rate of exhumation at the end of M1, which is compatible with a very low dipping structure. The outermost rim microns in A-type gamets often show one or two small $X_{\text {grs }}$ peaks that could be related to the emplacement of thrust nappes above the rocks during at least the last part of the process.

After M1, syn-D2 evolution is characterized by destabilization of garnet and kyanite. The decompressive and then retrograde paths of the Upper and Middle units led parts of the former M1 kyanite and staurolite 1 zones to the stability field of sillimanite (sillimanite 1 zone) and finally to andalusite stability conditions. This implies the removal of a 12-15 km column of rock from above the garnet zone level; most probably from levels even shallower, as there are no regional subtractive structures preserved above. In the high grade rocks of the Lower Unit, gamet-bearing assemblages are stable at lower pressures than those registered in the Middle Unit, suggesting that they probably correspond to late D2 stages of the crustal section evolution. This implies a near isothermal decompression of at least 19-20 km during D2 deformation. Assuming the removal of the $12-15 \mathrm{~km}$ overburden from above, an intemal thinning of 4-8 $\mathrm{km}$ can be deduced only in the BSZ. Syn-D2 destabilization of muscovite in the migmatitic gneisses from the Lower Unit indicates that Ms-out conditions were reached, but cordieritebearing migmatites are only present in the lowermost structural levels of the high-grade core of the dome. Small new pressure increments are in relation to late-D2 thrust sheets, probably emplaced around $319 \mathrm{Ma}$, stacking migmatitic gneisses of the Lower Unit over the not migmatized rocks of the Middle Unit. The mean crustal thermal gradient calculated from the $P-T$ conditions of Sil $+\mathrm{Kf}$ s samples towards the end of D2 is around $33-37{ }^{\circ} \mathrm{C} / \mathrm{km}$, which is very close to that of the BSZ at the beginning of D2, and points to a thermal homogenization process. Strong exhumation and cooling of the medium grade rocks associated to the oblique overprinting of the M2 thermal structure on the M1 zones were probably produced during the domal uplift of the previously buried and heated mountain roots. The youngest ${ }^{40} \mathrm{Ar} /{ }^{39} \mathrm{Ar}$ ages of $\mathrm{S} 2$ foliations are c. $316 \mathrm{Ma}$ and the oldest post-S2 granitoids are dated c. $315 \mathrm{Ma}$ (Bea et al., 2009 and references therein), so this is a very accurate limit for the ending of D2 and M2 and for the beginning of D3 in this region, as it also occurs in other parts of the Iberian Massif (Valle Aguado et al., 2005).

A new small clockwise loop occurred during D3 and D4 (M3-M4) evolution of some rocks of the Upper and Middle units. D3 folding did not produce a significant thickening effect, as there is not a second generation of kyanite, nor a post-D2 episode of gamet growth. The final syn-D4 branch of the P-T-t trajectories correspond to the last activity of ductile normal and normal oblique-slip shear bands, some of them crosscutting post-tectonic granites, aged 300-295 Ma, or their thermal aureoles. New crystallization of post- $\mathrm{S} 2$ staurolite 2 , andalusite and sillimanite 2, developed in D3 and D4 hinge zones, S3, S4 and C planes. Relict metastable kyanite was sometimes transformed directly into andalusite and this one is partially overgrown by fibrolite. Retrograde recrystallization of the Lower Unit continued during D3 with extensive transformation of gamet to biotite + sillimanite 2 and finally during D4. The M3 set of isograds on the Upper and Middle units is located close to the highgrade outcrops of the Lower Unit, and is roughly parallel to D3 axial races, though low-dipping M3 zones are oblique to steeply-dipping D3 axial surfaces. This thermal spike may be related to the thermal relaxation after D3 folding of the thermal structure of the dome, to the heating induced by large granite in trusions or to both. Multiple thermal peaks are characteristic of tectonic unroofing in metamorphic terranes (Whitney and Dilek, 1998).

\section{Discussion and conclusions}

The main thickening episode D1 occurred at around 354-347 Ma in this region. P-T conditions established from rocks of the garnet zone imply a burial depth considerably larger than the Upper Unit could have produced by thickening linked to D1 folding alone. Most of this depth can be explained by assuming an overlying allochthonous nappe and perhaps synorogenic deposits coeval with its emplacement, subsequently removed by extension. The main allochthonous complex of the Iberian Massif is known as the Galicia-Trás-os-Montes Zone (GTMZ). It was thrust upon the $\mathrm{CIZ}$ and is preserved in the NW part of the massif (Fig. 1). The GTMZ is formed by allochthonous units derived from the Gondwanan extemal margin and by far-traveled terranes, including ophiolites and high-pressure rocks (Arenas et al., 1986), which were emplaced parallel to the orogenic rend marked by the Ibero-Armorican arc (Gómez Barreiro et al., 2007; Martínez Catalán, 1990; Martínez Catalán et al., 2007). The GTMZ can be correlated to other allochthons widely represented in the Variscan belt of Central Europe (Martínez Catalán, 1990; Martínez Catalán et al, 2007; Matte, 1991). Its thickness reached in NW Iberia around $20 \mathrm{~km}$ (Martinez Catalán et al., 2007). The ${ }^{40} \mathrm{Ar} /{ }^{39} \mathrm{Ar}$ age of its basal thrust is approximately 343 Ma (Dallmeyer et al., 1997), which is also consistent with the D1 ages obtained in the Somosierra region. We propose that the emplacement of a thick GTM 2 nappe around 347-343 Ma may explain the crustal thickening and regional Barrovian metamorphism in the internal zones of the Iberian Massif: The same approach has been used to model similar initial P-T conditions in the autochthon of NW Spain by Alcock et al. (2009), although there, it is strongly supported by the proximity of the GTMZ to the modeled areas.

The maximum burial depths in the $\mathrm{Cl} Z$ are related to $\mathrm{M} 1$ and restricted to an axial fringe parallel to the orogenic rend. It can be raced from close to the GTMZ in the NW (Alcock et al., 2009) to the studied area. This fact, and the absence of nappes other than the GTMZ, suggest SE-directed emplacement of a tongue-shaped nappe subparallel to the orogenic rend, consistent with D2 regional tectonic ransport directions. Altematively, the tongue-like shape of the allochthon can be explained as being due to or enhanced by D3 folding in the core of the Central Iberian arc (Aerden, 2004; Martínez Catalán, 2011; Staub, 1926).

Both interpretations are consistent with oblique dexal continental convergence (Carosi and Palmeri, 2002; Carosi et al., 2009; Corsini and Rolland, 2009; Schulmann and Gayer, 2000; Shelley and Bossière, 2000). Also in both hypotheses, the mechanism of emplacement may be related to lateral escape tectonics, gravitational spreading (Aerden, 2004) or a combination of both (Fig. 9).

SE-directed ductile flow, development of late NW-directed detachments and buoyant uplift of thermally weakened crust explain the main features of the D2 decompression. The latter includes IP/HT (M2) overprinting of the M1 Barrovian zonation, uplift of the orogenic roots, individualization of gneiss domes (Doblas, 1991; Doblas et al., 1994; Escuder Viruete et al., 1994; Martinez et al., 1988), which are aligned towards the GTMZ in a core complex-like system parallel to the orogenic trend, and the large volume of anatectic granitoids (Fig. 10). A set of NWdirected extensional detachments bracketed between 323 and $314 \mathrm{Ma}$ and previous to upright folding is preserved in the GTMZ allochthon (Gómez Barreiro et al., 2007; Martínez Catalán et al., 2007), and it is coeval with the obtained $327-316 \mathrm{Ma}{ }^{40} \mathrm{Ar} /{ }^{39} \mathrm{Ar}$ ages of extension in the ICS. E-W extension in the nearby Mondoñedo Nappe was probably active between 325 and $300 \mathrm{Ma}$ (Martínez Catalán et al., 2003 and references therein). This main decompressive episode is also consistent with the 325-315 Ma age of the correlative process in other parts of the southern 

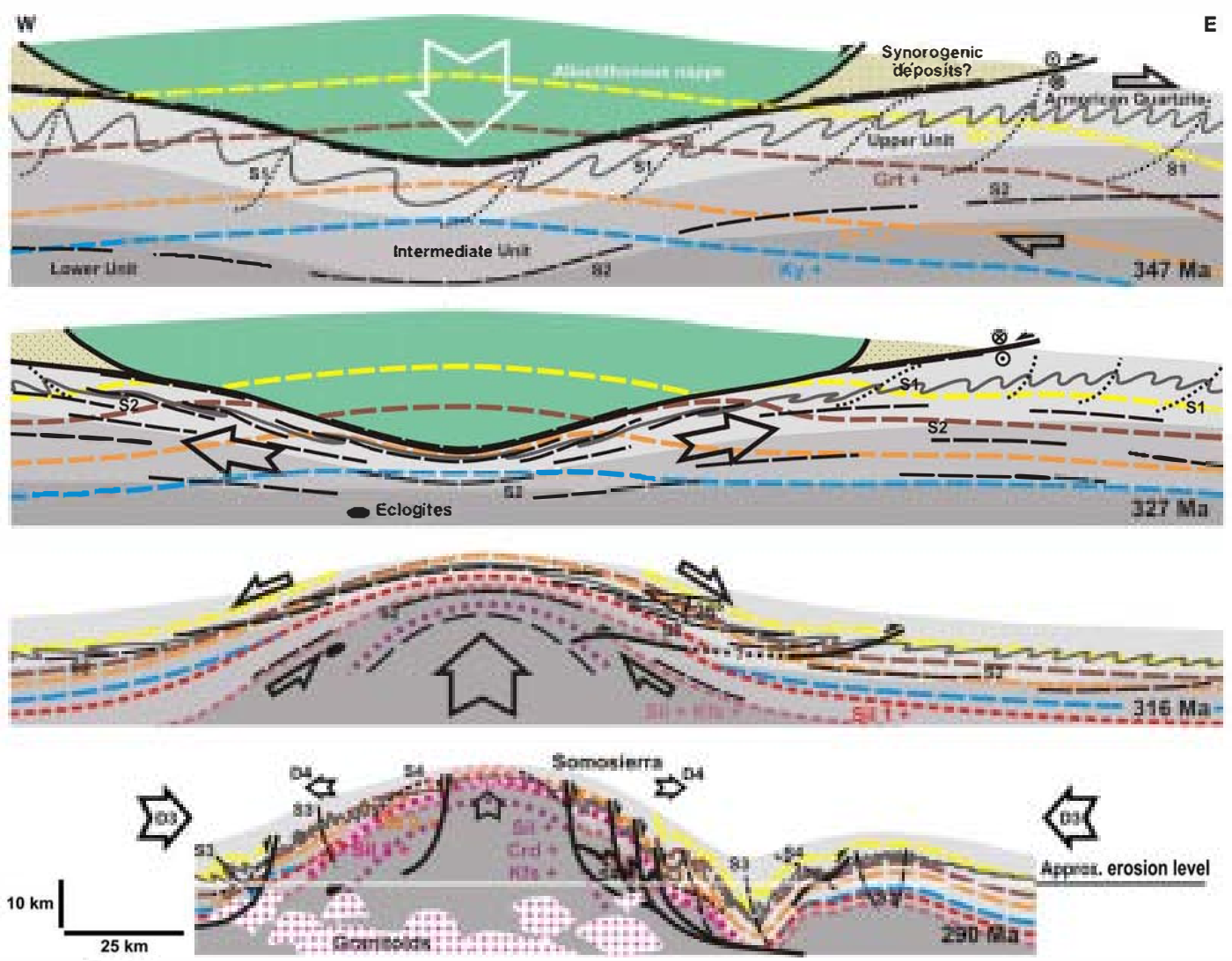

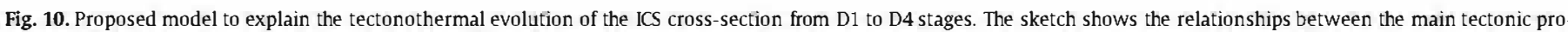
cesses and the successive overprinting of metamorphic zonings.

Variscan Chain, such as the French Massif Central, where late postmetamorphic thrusts (Cassard et al., 1993) or gravitational nappes (Aerden, 1998; Aerden and Malavieille, 1999) are also described; or the Variscan basement of Sardinia, where syn-D2 shearing and exhumation have been dated in $320-315 \mathrm{Ma}\left({ }^{40} \mathrm{Ar} /{ }^{39} \mathrm{Ar}\right.$ laser ages of white micas; Di Vincenzo et al., 2004) or c. 320 Ma (U-Th-Pb by (El.A)-ICP-MS in monazites; Carosi et al., 2012).

While the thermally weakened mid-lower crust was undergoing orogen-parallel extension and decompression, deep-seated deformation propagated towards more external orogenic zones. The implied understacking of new lithospheric slabs decoupled from the extending domain explains the absence of astenospheric mantle uplift in cases like these (Block and Royden, 1990; Meissner and Mooney, 1998; Thompson and McCarthy, 1990), where peak temperature conditions were achieved prior to the main phase of decompression. The absence of Variscan zircons prior to $312 \mathrm{Ma}$ in the granulitic lower crust of the ICS (Fernández-Suárez et al., 2006) confirms the late underthrusting of crustal units not previously recrystallized in Variscan times.

After D3 upright folding and D4 localized flattening about domal structures occurred under M3, LP/HT conditions, D4 (or regionally equivalent) extensional shear bands with strike-slip components (Hernández Enrile, 1991; Macaya et al., 1991; Martínez et al., 1996; Valle Aguado et al., 2005) completed emplacement of the allochthonous slab and exhumation of the high-grade rocks of the orogenic root.

\section{Acknowledgments}

This work has been supported by the internal project of the Spanish Geological Survey (IGME): Cartografia Geológica de las hojas del Mapa Geológico de España 1:200.000, no. 38 y 45. R.A and J.R.M.C have been funded by research projects CGI2007-65338-C02-01 and -02/BTE of the Dirección General de Programas y Transferencia del Conocimiento (Spanish Minis of Science and Innovation), co-financed by the
European Funds of Regional Development (FEDER). Valuable constructive criticism and helpful suggestions from D.G.A.M. Aerden, R. Carosi and one anonymous reviewer are gratefully acknowledged.

\section{Appendix A. Supplementary data: Representative chemical analyses of minerals}

\section{Appendix B. ${ }^{40} \mathrm{Ar} /{ }^{39} \mathrm{Ar}$ Analytical techniques}

Supplementary data to this article can be found online at http:// dx.doi.org/10.1016/j.tecto.2012.10.005.

\section{References}

Aerden, D.G.A.M., 1998. Tectonic evolution of the Montagne Noire and a possible orogenic model for syn-collisional exhumation of deep rocks, Hercynian belt, France. Tectonics $17,62-79$

Aerden, D.G.AM., 2004. Correlating deformation in Variscan NW-Iberia using porphyroblasts; implications for the Ibero-Armorican Arc. Journal of Structural Geology 26, 177-196.

Aerden, D.GA.M., Malavieille, J., 1999. Origin of a large-scale fold nappe in the Montagne Noire (Variscan Belt, France).Joumal of Stuctural Geology 21, 1321-1333.

Alcock, J.E., Martínez Catalán, J.R., Arenas, R., Díez Montes, A., 2009. Use of thermal modelling to assess the tectono-metamorphic history of the Lugo and Sanabria gneiss domes, Northwest Iberia. Bulletin de la Societe Geologique de France 180 , $179-197$.

Arenas, R, 1991. Opposite P, T, t paths of Hercynian metamorphism between the upper units of the Cabo Ortegal Complex and their substratum (northwest of Iberian Massif). Tectonophysics 191, 347-364.

Arenas, R., González Lodeiro, F., Peinado, M., 1982. La zona de cizalla de Berzosa-Riaza en el sector septentrional. Influencia sobre la configuración de las zonas metamórficas. Cuademos do Iaboratorio Xeoloxico de Iaxe 3, 123-161.

Arenas, R, Gil Ibarguchi, J.I., González Lodeiro, F., Klein, E., Martínez Catalán, J.R., Ortega Gironés, E., Pablo Maciá, J.G., de Peinado, M., 1986. Tectonostratigraphic units in the complexes with mafic and related rocks of the NW of the Iberian Massif. Hercínica II, 87-110. 
Arenas, R., Fúster, J.M., González Iodeiro, F., Macaya, J., Martín Parra, L.M., Martínez Catalán, J.R. Villaseca, C, 1991. Evolución metamórfica hercínica de la región de Segovia (Sierra de Guadarrama). Revista de la Sociedad Geológica de España 4, 195-201.

Badham,J.P.N., Halls, C., 1975. Microplatetectonics, oblique collisions and the evolution of the Hercy nian orogenic systems. Geology 2,373-376.

Barbero, L., Villaseca, C, 2000. Eclogite facies relics in metabasites from the Sierra de Guadarrama (Spanish Central System): $\boldsymbol{P}-T$ estimations and implications for the hercynian evolution. Mineralogical Magazine 64, 815-836.

Bea, F., Pesquera, A, Montero, P., Torres-Ruíz, J., Gil-Crespo, P.P., 2009. Tourmaline ${ }^{4 \bullet} \mathrm{Ar} /$ ${ }^{39} \mathrm{Ar}$ chronology of tourmaline-rich rocks from Central Iberia dates the main Variscan deformation phases. Geologica Acta 7, 399-412.

Beaumont, C, Jamieson, R.A., Nguyen, M.H., Lee, B., 2001. Himalayan tectonics explained by extrusion of a low-viscosity crustal channel coupled to focused surface denudation. Nature 414, 738-742.

Bischoff, L., Schäfer, G., Schmidt, K., Walter, R., 1973. Zur geologie der mittleren Sierra de Guadarrama. Münstersche Forschungen zur Geologie und Palaeontologie 28, 27-30.

Block, L., Royden, L.H., 1990. Core complex geometries and regional scale flow in the lower crust. Tectonics 9, 557-567.

Capote, R., Fernández Casals, M.J., Gonzáez Lodeiro, F., Iglesias, M., 1977. El límite entre las zonas Astur Occidental-Leonesa y Galáico-Castelllana en el Sistema Central. Boletín Geológico y Minero 88, 517-520.

Carosi, R., Palmeri, R., 2002. Orogen-parallel tectonic transport in the Variscan belt of northeastern Sardinia (Italy): implications for the exhumation of medium-pressure metamorphic rocks. Geological Magazine 139, 497-511.

Carosi, R., Frassi, C., Montomoli, C., 2009. Defor mation during exhumation of medium- and high-grade metamorphic rocks in the Variscan chain in northern Sardinia (Italy). GeologicaIJournaI 44, 280-305.

Carosi, R., Montomoli, C., Tiepolo, M., Frassi, C., 2012. Geochronological constraints on post-collisional shear zones in the Variscides of Sardinia (Italy). Terra Nova 24, 42-51 http://dxdoi.org/10.1111/j.1365-3121.2011.01035.x.

Cassard, D., Feybesse, J.L., Lescuyer, J.L., 1993. Variscan crustal thickening, extension and late overstacking during the Namurian-Westphalian in the western Montagne Noire (France). Tectonophysics 222, 33-53.

Corsini, M., Rolland, Y., 2009. Late evolution of the southern European Variscan belt: exhumation of the lower crust in a context of oblique convergence. Comptes Rendus Geoscience $341,214-233$

Dallmeyer, R.D., Martínez Catalán, J.R., Arenas, R., Gil Ibarguchi, J.I., Gutiérrez-Alonso, G., Farias, P., Aller, J., Bastida, F., 1997. Diachronous Variscan tectonothermal activity in the NW Iberian Massif: evidence from ${ }^{4 \boldsymbol{A}} \mathrm{Ar} /{ }^{39} \mathrm{Ar}$ dating of regional fabrics. Tectonophysics 277, 307-337.

Dewey, J.F., Hempton, M.R., Kidd, W.S.F., Saroglu, F., Sengör, AM.C, 1986. Shortening of continental lithosphere: the neotectonics of Eastern Anatolia - a young collision zone. In: Coward, M.P., Ries, A.C (Eds.), Collision TectonicsSpecial Publication. Geological Society of London 19, 1-36.

Di Vincenzo, G., Carosi, R, Palmeri, R., 2004. The relationship between tectono-metamorphic evolution and argon isotope records in white mica: constraints from in situ ${ }^{40} \mathrm{Ar}-{ }^{39} \mathrm{Ar}$ laser analysis of the Variscan basement of Sardinia (Italy). Joumal of Petrology 45, 1013-1043.

Dias, R., Ribeiro, A, 1995. The Ibero-Armorican Arc: a collision effect against an irregular continent? Tectonophysics 246, 113-128

Díez Balda, M.A., Martínez Catalán, J.R., Ayarza Arribas, P., 1995. Syn-collisional extensional collapse parallel to the orogenic trend in a domain of steep tectonics. The Salamanca Detachment Zone (Central Iberian Zone, Spain). Journal of Structural Geology 17, 163-182

Doblas, M., 1991. Late Hercynian extensional and transcurrent tectonics in Central Iberia. Tectonophysics $191,325-334$.

Doblas, M., López-Ruíz, J., Oyarzun, R., Mahecha, V., Sánchez Moya, Y., Hoyos, M., Cebriá, J.M., Capote, R., Hernández Enrile, J.L., Lillo, J., Lunar, R., Ramos, A Sopeña, A, 1994. Extensional tectonics in the central Iberian Peninsula during the Variscan to Alpine transition. Tectonophysics 238, 95-116.

England, P.C., 1982. Some numerical investigations of large scale continental deformation. In: Hsii, K.J. (Ed.), Mountain Building Processes. Academic Press, New York, pp. 129-139.

EscuderViruete, J., Arenas, R, Martínez Catalán,J.R, 1994. Tectonothermalevolution associated with variscan crustal extension in the Tormes Gneis Dome (NW Salamanca, Iberian Massif, Spain). Tectonophysics 238, 1-22.

Escuder Viruete, J., Hernáiz Huerta, P.P., Valverde-Vaquero, P., Rodríguez Fernández, R. Dunning, G., 1998. Variscan extension in the Iberian Massif: structural, metamor phic and geochronological evidence from the Somosierra sector of the Sierra de Guadarrama (Central Iberian Zone, Spain). Tectonophysics 290, 87-109.

Fernández-Suárez, J., Arenas, R., Jeffries, T., Whitehouse, M.J., Villaseca, C., 2006. A U-Pb study of zircons from a lower crustal granulite xenolith of the Spanish Central System: a record of Iberian lithospheric evolution from Neoproterozoic to the Triassic. Journal of Geology 114, 471-483.

Gebauer, D., Martínez-García, E., Hepburn, J.C., 1993. Geodynamic Significance, Age and Origin of the Ollo de Sapo augengneiss (NW Iberian Massif, Spain): Annua Meeting of the Geological Society of America, Boston, Abstracts with Programs, 342.

Gómez Barreiro, J., Martínez Catalán, J.R., Arenas, R, Castiñeiras, P., Abati, J., Díaz García, F., Wijbrans, J.R., 2007. Tectonic evolution of the upper allochthon of the Órdenes complex (northwestern Iberian Massif): structural constraints to a polyorogenic periGondwanan terrane. In: Linnemann, U., Nance, R.D., Kraft, P.,Zulauf, G. (Eds.), Theevolution of the Rheic Ocean: From Avalonian-Cadomian active margin to AlleghenianVariscan collisionGeological Society of America Special Papers 423, 315-332. views in Mineralogy, voL 13. Mineralogical Society of America, Washington D.C, pp. $357-467$

Hames, W.E., Cheney, J.T., 1997. On the loss of ${ }^{4}{ }^{\bullet} \mathrm{Ar}^{*}$ from muscovite during polymetamorphism. Geochimica et Cosmochiica Acta 61, 3863-3872.

Hernández Enrile, J.L., 1991. Extensional tectonics of the Toledo ductile-brittle shear zone, central Iberian Massif. Tectonophysics 191, 311-324.

Holland, T.J.B., Powell, R., 1985. An internally consistent thermodynamic dataset with uncertainties and correlations. 2, Data and results. Journal of Metamorphic Geology 3, 343-370

Holland, T.J.B., Powell, R, 1990. An enlarged and updated internally consistent thermodynamic dataset with uncertainties and correlations: the system $\mathrm{K}_{2} \mathrm{O}-\mathrm{Na}_{2} \mathrm{O}-\mathrm{CaO}$ $\mathrm{MgO}-\mathrm{MnO}-\mathrm{FeO}-\mathrm{Fe}_{2} \mathrm{O}_{3}-\mathrm{Al}_{2} \mathrm{O}_{3}-\mathrm{TiO}_{2}-\mathrm{SiO}_{2}-\mathrm{C}-\mathrm{H}_{2}-\mathrm{O}_{2}$. Journal of Metamorphic Geology 8, 89-124.

Holland, T.J.B., Powell, R., 1992. Plagioclase feldspars: activity-composition relations based upon Darken's Quadratic Formalism and Iandau theory. American Mineralogist $77,53-61$.

Holland, T.J.B., Powell, R., 1998. An internally consistent thermodynamic dataset for phases of petrological interest. Journal of Metamorphic Geology 16, 309-343.

House, M.A. Hodges, K.V., 1994. Limits on the tectonic significance of rapid cooling events in extensional settings: insights from the Bitterroot metamorphic core complex, Idaho-Montana. Geology 22, 1007-1010.

Koppers, A.A.P., 2002. ArArCALC-sof tware for ${ }^{40} \mathrm{Ar} /{ }^{39} \mathrm{Ar}$ age calculations. Computers and Geosciences 28,605-619.

Koppers, A.A.P., Staudigel, H., Wijbrans, J.R., 2000. Dating crystalline groundmass separates of altered Cretaceous seamount basalts by the $\mathrm{Ar}^{40} / \mathrm{Ar}^{39}$ incremental heating technique. Chemical Geology 166, 139-158.

Kramar, N., Cosca, M.A. Hunziker,J.C., 2001. Heterogeneous ${ }^{40} \mathrm{Ar}^{*}$ distributions in naturally deformed muscovite: in-situ UV-Iaser ablation evidence for microstructurally controlled in ragrain diffusion. Earth and Planetary Science Ietters 192, 377-388.

Lee, J.K.W., 1995. Multipath diffusion in geochronology. Contrib. Min. Petrol. 120, 60-82

Lips, A.W.W., 1998. Temporal constraints on the kinematics of the destabilization of an orogen: Syn-to post-orogenic extensional collapse of the Northern Aegean Region. Geologica Ultraiectina 166, 224.

Lips, A.L.W., White, S.H., Wijbrans, J.R., $1998 .{ }^{40} \mathrm{Ar} /{ }^{39} \mathrm{Ar}$ laserprobe direct dating of discrete deformational events: continuous record of Early Alpine tectonics in the Pelagonian Zone, NW Aegean area, Greece. Tectonophysics 298, 133-153.

Macaya,J., González Lodeiro, F., Martínez Catalán,J.R., Álvarez, F., 1991. Continuous deformation, ductile thrusting and backfolding of cover and basement in the Sierra de Guadarrama, Hercynian orogen of central Spain. Tectonophysics 191, 291-309.

Martínez Catalán, J.R., 1990. A non-cylindrical model for the northwest Iberian allochthonous terranes and their equivalents in the Hercynian belt of Western Europe. Tectonophysics 179, 253-272.

Martínez Catalán, J.R., 2011. The Central Iberian arc, an orocline centred in the Iberian Massif and some implications for the Variscan belt. International Journal of Earth Sciences http://dx.doi.org/10.1007/S00531-011-0715-6.

Martínez Catalán, J.R., Arenas, R, Díez Balda, M.A., 2003. Large extensional structures developed during emplacement of a crystalline thrust sheet: the Mondoñedo nappe (NW Spain). Journal of Structural Geology 25, 1815-1839.

Martínez Catalán, J.R. Arenas, R., Díaz García, F., González Cuadra, P., Gómez Barreiro, J., Abati, J., Castiñeiras, P., Fernández Suárez, J., Sánchez Martínez, S., Andonaegui, P., González Clavijo, E., Díez Montes, A, Rubio Pascual, F.J., Valle Aguado, A, 2007. Space and time in the tectonic evolution of the northwestern Iberian Massif: Implica tions for the Variscan belt. In: Hatcher Jr., R.D., Carlson, M.P., McBride, J.H., Martinez Catalán,J.R. (Eds.), 4-D Framework of Continental CrustGeological Society of America Memoir 200, 403-423.

Martínez, F.J., Julivert, M., Sebastian, A, Arboleya, M.L., Gil-Ibarguchi, J.I., 1988. Struc tural and thermal evolution of high-grade areas in the northwestern parts of the Iberian Massif. American Journal of Science 28, 969-996

Martínez, F.J., Carreras,J., Arboleya, M.L., Dietsch, C, 1996. Structural and metamorphic evidence of local extension along the Vivero fault coeval with bulk crustal shortening in the Variscan chain (NW Spain). Journal of Structural Geology 18, 61-73.

Matte, Ph., 1991. Accretionary history and crustal evolution of the Variscan belt in Western Europe. Tectonophysics 196, 309-337.

McDougall, I., Harrison, T.M., 1999. Geochronology and Thermochronology by the ${ }^{4 \bullet} \mathrm{Ar} /$ ${ }^{39}$ Ar Method. Oxford University Press, Oxford . (269 pp.)

Meissner, R., Mooney, W., 1998. Weakness of the lower continental crust: a condition for delamination, uplift, and escape. Tectonophysics 296, 47-60.

Molnar, P., Tapponnier, P., 1975. Cenozoic tectonics of Asia: eff ects of a continental collision. Science $189,419-426$.

Montero, P., Bea, F., González-Iodeiro, F., Talavera, C., Whitehouse, M.J., 2007. Zircon ages of the meta-volcanic rocks and metagranites of the Ollo de Sapo Domain in central Spain: implications for the Neoproterozoic to early Palaeozoic evolution of Iberia. Geological Magazine 144, 963-976.

Mulch, A, Cosca, M.A. Handy, M.R, 2002. In-situ UV-laser ${ }^{4 \bullet} \mathrm{Ar} /{ }^{39} \mathrm{Ar}$ geochronology of a micaceous mylonite: an example of defect-enhanced argon loss. Contrib. Min. Petrol. $142,738-752$

Pérez-Estaún, A, Martinez-Catalán, J.R., Bastida, F., 1991. Crustal thickening and deformation sequence in the footwall to the suture of the Variscan belt of northwest Spain. Tectonophysics 191, 243-253.

Powell, R, Holland, T.J.B., 1985. An internally consistent dataset with uncertainties and correlations. 1, methods and a worked example. Journal of Metamorphic Geology 3, 327-342.

Powell, R, Holland, T.J.B., 1988. An internally consistent dataset with uncertainties and correlations. 3, applications to geobarometry, worked examples and a computer program. Journal of Metamorphic Geology 6, 173-204. 
Ramberg, H., 1980. Diapirism and gravity-collapse in the Scandinavian Caledonides. Journal of the Geological Society of London 137, 262-270.

Ring, U., Brandon, M.T., Willett, S.D., Lister, G.S., 1999. Exhumation processes. In: Ring, U., Brandon, M.T., Lister, G.S., Willett, S.D. (Eds.), Exhumation Processes: Normal Faulting, Ductile Flow and ErosionGeological Society, Iondon, Special Publications 154, 1-27.

Schulmann, K., Gayer, R., 2000. A model for a continental accretionary wedge developed by oblique collision: the NE Bohemian Massif. Journal of the Geological Society of London $157,401-416$.

Selverstone, J., 1988. Evidence for east-west crustal extension in the Eastern Alps: implications for the unroofing history of the Tauern Window. Tectonics 7, 87-105.

Shelley, D., Bossière, G., 2000. A new model for the Hercynian Orogen of Gondwanan France and Iberia. Journal of Structural Geology 22, 757-776.

Simancas, J.F., Martínez Poyatos, D., Expósito, I., Azor, A., González Lodeiro, F., 2001. The structure of a major suture zone in the SW Iberian Massif: the Ossa-Morena/ Central Iberian contact. Tectonophysics 332, 295-308.

Simancas, J.F., Carbonell, R., González Lodeiro, F., Pérez Estaún, A., Juhlin, C., Ayarza, P., Kashubin, A., Azor, A., Martínez Poyatos, D., Almodóvar, G.R., Pascual, E., Sáez, R. Expósito, I., 2003. Crustal structure of the transpressional Variscan orogen of SW Iberia: SW Iberia deep seismic reflection profile (IBERSEIS). Tectonics 22, 1062 http://dx.doi.org/10.1029/2002TC001479.

Staub, R, 1926. Gedanken zum Strukturbild Spaniens. Vierteljs des Naturforschende Gesellschaft in Zürich 71, 196-260.

Tapponnier, P., 1977. Evolution tectonique du système alpin en Méditerranée: poinçonnement et écrasement rigide-plastique. Bulletin. Société Géologique de France 7, 437-460.

Tapponnier, P., Molnar, P., 1976. Slip-line field theory and large scale continental tectonics. Nature 264, 319-324.

Thompson, G.A., McCarthy, J., 1990. A gravity constraint on the origin of highly extended terranes. Tectonophysics $174,197-206$.
Tracy, R.J., 1982. Compositional zoning and inclusions in metamorphic minerals. In: Ferry, J.M. (Ed.), Characterization of Metamorphism Through Mineral Equilibria. Reviews in Mineralogy, voL 10. Mineralogical Society of America, Washington D.C., pp. 355-397.

Valle Aguado, B., Azevedo, M.R., Schaltegger, U., Martínez Catalán, J.R. Nolan, J., 2005 $\mathrm{U}-\mathrm{Pb}$ zircon and monazite geochronology of Variscan magmatism related to synconvergence extension in central northern Portugal. Lithos 82, 169-184.

Valverde-Vaquero, P., Dunning, G., 2000. New U-Pb ages for Early Ordovician magmatism in Central Spain. Journal of the Geological Society of London 157, 15-26.

Vance, D., Ayres, M., Kelley, S.P., Harris, N., 1998. The thermal response of a metamorphic belt to extension: constraints from laser Ar data on metamorphic micas. Earth and Planetary Science Letters 162, 153-164.

Vialette, Y., Casquet, C., Fúster, J.M., Ibarrola, E., Navidad, M., Peinado, M., Villaseca, C. 1987. Geochronological study of orthogneisses from the Sierra de Guadarrama (Spanish Central System). Neues Jahrbuch für Mineralogie Monatshefte 10 465-479.

Whitney, D.L., Dilek, Y., 1998. Characterization and interpretation of $\boldsymbol{P}-\boldsymbol{T}$ paths with multiple thermal peaks. In: Treloar, P.J., O'Brien, P.J. (Eds.), What drives metamorphism and metamorphic reactions?Special Publication. Geological Society of Iondon $138,53-60$.

Whitney, D.L., Evans, B.W., 2010. Abbreviations for names of rock-forming minerals. American Mineralogist 95, 185-187.

Wijbrans, J.R., McDougall, I., 1986. ${ }^{4 \bullet} \mathrm{Ar} /{ }^{39} \mathrm{Ar}$ dating of white micas from an Alpine highpressure metamorphic belt on Naxos (Greece): the resetting of the argon isotopic system. Contributions to Mineralogy and Petrology 93, 187-194.

Wijbrans, J.R., Pringle, M.S., Koppers, A.A.P., Scheveers, R., 1995. Argon geochronology of small samples using the Vulkaan argon laser-probe. Koninklijke Nederlandse Akademie van Wetenschappen, Amsterdam 98, 185-218. 